No. 2(71), 2021, pp. 19-66

https://doi.org/10.12797/Politeja.18.2021.71.02

\author{
Dominique BOUCHET (D) \\ University of Southern Denmark \\ dom@sam.sdu.dk
}

\title{
A TRANSDISCIPLINARY AND CROSS- CULTURAL INTRODUCTION TO THE ISSUE OF HUMAN RIGHTS IN A “GLOCAL” WORLD
}

\author{
ABOUT THE REVERSAL OF THE RELATION BETWEEN \\ THE LOCAL AND THE GLOBAL AND ITS CONSEQUENCES \\ FOR THE FERTILITY AND QUALITY OF HUMAN RELATIONS
}

ABSTRACT The purpose of my contribution is to provide a general overview of the issue at stake when today over the world people debate human rights. In order to do so I will rely on and both differentiate and associate philosophical, anthropological, ethnological, historical, sociological, political, and psychological approaches. Let me stress that this is not at all to contribute to a muddled understanding of the issue of human rights that necessarily has to be perceived differently depending on the field of research. On the contrary, it is in fact to articulate that the issue of human rights can only be understood from a transdisciplinary perspective; and that cross-cultural communication is required to approach the question of 'values' and 'rights' in our globalized world.

Keywords: human rights, discourse, globalization, modernity, social change 
The concept of human rights was developed through philosophical thoughts made possible in a specific historical and political context. It is based on the anthropological fact that human beings are bound to figure out how they should relate to their surroundings, but they did not necessarily have to develop such an understanding of their common situation. Still, every individual on this planet today, when confronted to the concept of 'human rights,' consciously or not, necessarily relates to it through their socio-psychological and socio-cultural predispositions. Likewise, every community somehow has to make choices related to its perception. Let me stress that as a transdisciplinary academic my understanding is of course limited by what I have learned during my career.

\section{A TRANSDISCIPLINARY PERSPECTIVE}

Thanks to philosophy, we learned to distinguish between authority and authoritarian, and between common, universal and uniform. Thanks to anthropology, we realized what difference a symbolic representation makes. Thanks to ethnology, we were confronted with the fact that the relation humans have with the world they live in could be radically different from the ones we have today and even to the ones we knew from history. Thanks to history, we kept track of important changes in the mode of relation between power and beliefs, as well as among modes of settlement, production, distribution, interaction, and regulation. We could not do that before specific new understandings made it possible to ask new kind of questions and to develop new branches of historical thoughts such as economic history and art history, for instance. On top of this, and I mean that almost literally, we ended up realizing how our own perception and conception of what was happening to us and what we were doing together on this planet actually was constantly informed and impacted by our social interactions and representations at a historical moment of time depending on the extent and duration of those interactions.

I will come back to all this, of course. I am only introducing now how I intend to picture the concept and issue of human rights; a little like we scientifically ended up realizing that today the making, perception, appreciation, and evaluation of a painting actually depends on so many factors. Needless to say, one can still be satisfied with the feelings that the contemplation of a painting gave him or her; but we should remember that today the same painting in an exhibition can as easily be seen as hilarious by a group of visitors as it can trigger feelings of serenity or pain. Again, it depends on who we are - whatever that means - and how we feel on that day, or what is our education, or what is the context we are facing, or whether we are watching the painting alone or in a group, and so on. The reader should not conclude that I am inclined to support relativism or subjectivism. On the contrary, I am pointing out the importance and specificity of a scientific approach: it strives for and builds on objectivity, which includes the awareness of - and reflection upon - one's individual and group's prejudices. 
Sociology, psychology, and political science did teach us how to perceive, identify and relate critically to ideologies and self-confidences. Historically, and thanks to science and philosophy, we are now able to relate critically rather than dogmatically to any past and present understanding of what humans have believed about the world and themselves, and this is why the issue of human rights has acquired a central place in contemporary political and ethical debates.

This does not mean that humans have now reached a scientific definition of human rights. On the contrary, we historically realized that such a definition can neither be obtained nor should be desired. Such a scientific pursuit would in fact consist of a denial of the specificity of mankind: Humans can dream of controlling things, but they cannot control their dreams. Technique and science do serve and broaden the scope of human dreams, but they cannot turn human desire into a thing. Briefly speaking - I will come back to it: dreams are historical, desire is anthropological - science and technology are embedded in social change; they were shaped in history and still rely on social interactions. Further, social interactions are not rational; they cannot be managed like a machine. Human beings are not born rational; they learn a symbolic language and gain access to representations and meanings shared with others in social bonds. Thus, humans are metaphysical animals. They are biological beings inhabiting an environment filled with symbols; and symbols are not just signs as they always rely on cultural representation and interpretation.

Thanks to science and technology, we have learned that many other species on Earth also feel, learn, build, and communicate. ${ }^{1}$ It is not enough to point to the fact that humans think and interact, but it is necessary to stress the specificity of human feelings and thinking: Humans are beings of imagination and of the imaginary. ${ }^{2} \mathrm{Hu}-$ mans not only think and create, wonder and imagine; their mind and reasoning are always filled with feelings and emotions of a specific human kind. Call it angst or anxiety,

For more than half a century, scientific evidence has shown that certain monkeys have distinct signs for leopard, eagle, and snake (Edward O. Wilson, On Human Nature, Cambridge, MA 1978, p. 83). As soon as it perceives them, the animal gives meaning to the things of which its world is made. It takes material from the physical universe, from which it constructs its own 'objects' (... [25-44]). But this meaning never shows up as a human meaning: if the "given" datum has been well and truly interpreted, it has been interpreted in terms of an animal world which is not governed by the same set of meanings as ours. B. Cyrulnik, The Dawn of Meaning, New York 1993 [1991], pp. 25, 44. Original: La naissance du sens, Paris 1991, pp. 27, 48; or La naissance du sens, Paris 1995, pp. 27, 48.

2 When all is said and done, Being is Chaos, Abyss, Groundlessness. But it is also creation. It is to employ a Latin expression, a vis formandi (a power of formation) which is not predetermined and which superimposes on the Chaos a Cosmos, a World that is organised and ordered somehow or other. In the same way, the human too, is Abyss, Chaos, Groundlessness - not only in as much as it participates in being in general (for example, qua matter and qua living matter) but also in as much as we are beings of imagination and of the imaginary. The emergence of these determinations itself manifests the creation and the vis formandi that appertain to being as such, but these determinations also concretely realize the mode of being of the creation and the vis formandi specific to the properly human. C. Castoriadis, "Culture in a Democratic Society", in D.A. Curtis (ed.), The Castoriadis Reader, Oxford-Malden 1997, p. 342. Original: C. Castoriadis, "La culture dans une société démocratique", in C. Castoriadis (ed.), La montée de l'insignifiance. Les carrefours du labyrinthe IV., Paris 1996, p. 199. 
call it love - but not a virus, human intelligence, even when logical, remains ideological. Call it imaginative, call it imaginary, it cannot be reduced to either a mechanism or just a mere feeling. As the biologist and geneticist Albert Jacquard (1925-2013) once said: You can teach a computer to say, 'I love you,' but you can't teach it to love. ${ }^{3}$ I will add: you can feel the pain of your dog, but you cannot heal the wound of your heart, and even a single word can hurt your soul. As the great Spanish poet Antonio Machado wrote: It is nice to know that a glass is used to drink, the problem is that we do not know what thirst is for. ${ }^{4}$ Human interpretations, creations and relations are bound to be chaotic. Living in a symbolic universe, at any time in History, human individuals and societies will have to make sense and relate to each other and the world by making sense of it including of themselves. More impressive than moving mountains with technology, beings of imagination and of the imaginary did move the frontiers of social relations and time perception. Past, present and future have to be socially tamed. The question of who, why, when, and how do others belong must be answered.

Now, thanks to science, we've learned through history that as various communities met on the planet, even when claimed safe and certain, taming procedures and ways of answering questions remained dependent of social bonds. The contemporary legitimization process of human rights is an illustration of the complexity of the issues human societies have to face. Tangled up in chaotic inventive justification processes, human communities have always been bound to create a house of cards of values and norms, and to reflect upon how and why they did and could have done. The issue of human rights, so closely related to the issue of social identity is bound to be complex, which today means something different than the traditional understanding of 'not yet simplified.'

As Edgar Morin, one of the foremost contributors to the development of the transdisciplinary approach to inquiry, stresses: All knowledge operates through the selection of meaningful data and the rejection of data that are not meaningful. It does so by separating (distinguishing or disjointing) and unifying (associating, identifying), and by organizing into hierarchies (the primary, the secondary) and centralizing (around a core of master notions). These operations, which use logic, are in reality driven by 'supra-logical'principles of organization of thought, or paradigms: the hidden principles that govern ourperception of things and of the world without our being conscious of them. ${ }^{5}$

A. Jacquard, Petite philosophie à l'usage des non-philosophes, Paris 1997, p. 173.

A. Machado, Campos de Castilla. Edición de José Luis Cano, Madrid 1986, p. 149; my translation.

E. Morin, On Complexity, transl. by R. Postel, Cresskill 2008, p. 2. Original: E. Morin, Introduction à la pensée complexe, Paris 1990, p. 16. Edgar Morin approached a variety of subjects usually confined in isolated disciplines and developed a generative loop that became one of the trademarks of his complex thought and practice of inquiry. The difficulty of complex thought is that it must face messes (the infinite play of inter-retroactions), interconnectedness of phenomena, fogginess, uncertainty, contradiction. Born in 1921, Morin has contributed to complex thinking for over 60 years now and continues to be active in 2021. Main reference on complexity: E. Morin, La Méthode I: 1. La Nature de la Nature; 2. La Vie de la Vie; 3. La Connaissance de la Connaissance, Paris 2008; idem, La Méthode II : 3. Les Idées; 4. L'Humanité de l'Humanité; 5. Éthique, Paris 2008; idem, On Complexity; idem, On the Definition of Complexity, The United Nations University 1985. Edgar Morin is one of my top ten 
Thus, during the vague transition from a geocentric (Ptolemaic) to a heliocentric (Copernican) view of the world, the first contrast between the two worldviews was in the principle determining the selection and rejection of data. The supporters of the geocentric view rejected as meaningless all data that was inexplicable according to their worldview. The supporters of the other view used the same data as a foundation for conceptualizing the heliocentric system. The new system is made up of the same elements (the planets), and often uses the same calculations, but the entire worldview has changed. The rearranging of the Earth and Sun was much more than a simple permutation. It was rather a transformation of the center (the Earth) into a peripheral element, and of a peripheral element (the Sun) into the center. ${ }^{6}$

Today's transition from a local to a global view of the world calls for a more complex approach to science and politics. The challenge is the understanding of our planetary context. We must grasp the implications of a global, interconnected, uncertain world in an analytical and constructive manner. We have to relate to the reversal of the relation between the local and the global and its consequences for the fertility and quality of human relations between citizens on the planet. More than ever, political strategy requires locally and globally complex knowledge because strategy plays itself out by working with and against uncertainty, chance, the multiple play of interactions and retroactions (feedback loops). ${ }^{7}$

Complexus: that which is woven together. Unraveling the complexities of global interactions and their social impact is an enormous challenge. The effort to simplify a complex system makes it even more complex, especially if this simplification uncritically leads to concrete measures.

Thanks to history and social-psychology, we have learned how and why in times of great anxiety, human beings tend to reduce the complexity by finding one source to blame; scapegoating and conspiracy theories flourish. When facing great social changes and potential or even actual chaos, the tendency is to seek out absolute foundations, certainty, simplicity, and a framework that will make sense of the world and reduce anxiety. These frameworks are informed by reductionist and dualistic thinking that drastically reduces the complexity of the world. Cross cultural communication, local and global political strategy should build on complex knowledge.

\section{LOST IN TRANSLATION}

Émile Durkheim (1858-1917) wrote: For a long time it has been known that the first systems of representations with which men have pictured to themselves the world and themselves were of religious origins. (...) If philosophy and the sciences were born of religion, it is

masters: http://bouchet.dk/the-man/masters/; D. Bouchet, "Kompleksitetsparadigmet. Videnskabsteoretiske betragtninger om vor tids udfordringer med udgangspunkt i Edgar Morins værker", Paradigma, vol. 1, no. 1 (1986), pp. 7-17. I wish to dedicate this text to him.

6 E. Morin, On Complexity, p. 2 (original: E. Morin, Introduction à la pensée complexe, p. 16).

7 Ibid., pp. 5, 21. 
because religion began by taking the place of the sciences and philosophy. (...) Men owe to it not only a good part of the substance of their knowledge, but also the form in which the knowledge has been elaborated. ${ }^{8}$ Today it can be stressed that philosophy and science in fact cannot totally cut the link to their spiritual origins. However developed, critical and reflexive it may be, any human conception relies on the human language. The great importance of modern epistemology is to have definitely shown that scientific theories are not reflections but 'translations' of actual human experiences in a human language at a specific time and place. Science is truly an intellectual social construction. Even though universal science can have today a greater ability to explain and help all over the world much more efficiently than local religions, it does not mean that it is or will be able to convince that precisely this scientific argumentation can support universal human rights.

Every single human being is born into a pre-existing world of imaginary significations that makes sense at an individual and collective level. ${ }^{9}$ The uniformity, steadiness, and consistency of the systems of representations maintained in networks of human relations vary in relation to the challenges of diversity and intensity of confrontation within and between those networks.

Thus, the Durkheim quote I just cited is to be found in the very first chapter of his study of the elementary forms of religious life (1912) where he described and analyzed the most primitive religion known to man: the totemic system in Australia. However, Durkheim's ultimate purpose went well beyond the reconstruction of an archaic culture for its own sake; on the contrary, as in his The Division of Labor and Suicide, the great sociologist's concern ultimately both pertained to the present and was practical: If we have taken primitive religion as the subject of our research, it is because it has seemed to us better adapted than any other to lead to an understanding of the religious nature of man, that is to say, to show us an essential and permanent aspect of humanity..$^{10}$ What interests me here is the possibility to address and discuss the multiplicity and variety in space and time of the ways human populations related to their own ways and - when confronted with them - other's ways of making sense.

Though it is tempting to assume that the very advantage secured by religion is stability and thus continuity of culture, ${ }^{11}$ religious confrontations and historical developments have clearly shown that the variety of beliefs and rituals ended up in confrontations. Let's say it once again: human interpretations, creations, and relations are bound to be chaotic. Still, human conditions, interactions, and challenges clearly evolved. As different ways of making sense and of being together ended up in confrontations with each

8 É. Durkheim, The Elementary Forms of the Religious Life, transl. by J.W. Swain, London 1968 [1912], p. 9. Original: É. Durkheim, Les formes élémentaires de la vie religieuse. Le système totémique en Australie, Paris 1979 [1912], p. 12.

9 See notes 2 and 71.

10 É. Durkheim, The Elementary Forms..., p. 2.

11 W. Burkert, Creation of the Sacred. Tracks of Biology in Early Religions, Cambridge, MA-London 1996, p. 15. 
other, the question of how to deal with what is right for whom still has to be answered, even though no one seems to agree on it.

The issue of the human rights emerges from the historical development of the very same question of how and why humans ought to behave. It proceeds from similar fundamental motivations and proposes a modern answer quite in line with traditional ones. The terms 'modern' and 'traditional' here refer to the fact that historical developments have brought all local, so called primitive, traditional, modern societies together globally. Nowadays, different ways of being and staying together locally are challenged globally and it cannot be avoided. No community can flee to a new virgin location and remain unconcerned and immune. Anyway, the decision to withdraw still bears a trace of the choice: its historical development has not much in common with the original choices made by the primitive communities.

According to Émile Durkheim a religious system may be said to be 'most primitive' when: (a) it is found in a society whose organization is surpassed by no others in simplicity; and (b) it is possible to explain this system without making use of any element borrowed from any previous religion. ${ }^{12}$ When confronted with their discovery of what is globally agreed to be called 'human diversity' today many primitive and later traditional societies had to figure out what kind of beings those weird animals actually were. I will come back to it in due course.

Today all human communities agree with what science made evident. Still, it has not removed the issue of who among humans is right; it only brought it to a global level. Today even individuals and communities trying to delimit and divide or separate people, or to ignore or evade the issue, are caught in a global confrontation. They cannot confine it. The relation between the local and the global was turned upside down. The terms of all combats are inverted. The local cannot avoid the global and that makes a significant difference.

\section{CAUGHT IN CONFRONTATION}

The history of the human habitation on Earth is indeed revealing. Not only the history of the expansion, but also of the ideological perception of territory is worth attention. When humans found out mirroring images existing in different cultures, it gave an impetus to a redefinition of human condition and provided grounds for cross cultural understanding. As already mentioned, humans were bound to translate their experience in their own constitutive language and to make choices. They spread out over the planet many thousand years ago and kept on interpreting and translating the environment in relation to the different kinds of challenges they faced in different places and times. Climate changes and displacements of species are examples of such significant challenges.

12 É. Durkheim, The Elementary Forms..., p. 1. 
Thanks to geology and archaeology, we recently ${ }^{13}$ got to know worldwide that a great moment of change occurred twelve thousand years ago when the glaciers melted and as a consequence the level of the oceans rose a hundred and twenty meters submerging the great planes and radically altering Eurasia's ecosystems. Mentioning such events and factors clearly reminds us that the challenges humanity faces remain very much the same. They are related to the fact that our species does not control the planet but has to relate to it in a way that makes sense at a given moment of time in a given culture. When such events occur, what seems out of control is not only the external natural forces humans have to deal with, but also the inner appreciation human cultures have of those. Even though such events can take a long time, the loss of control does affect representations which no longer seem to make sense with certainty.

I said, 'recently' because geology formed into an organized science at the beginning of the $19^{\text {th }}$ century (and archaeology first emerged in the context of the rediscovery of the Greco-Roman past by cultivated elites of the Renaissance). Geology changed radically the relationship between man and the world, as it revealed the prodigious length of the times which preceded humanity and revived the countless living worlds which had succeeded one another on Earth. By so doing, this science encroached on the domain of the teachings of the Churches at a time when most cultures around the world knew of each other and were already confronted with the necessity of maintaining their ideological strife against chaos.

Thus, we see that the challenges societies have to meet are not only related to rifts initiated by geological evolutions, earth tremors, and climatic changes; all social realities constructed in the face of chaos can be brought into question by a mere contact with each other or through the questioning or redefinition of some elements of the sense-making system.

A scientific discipline even more recent than geology provided insights in a variety of ways and into ways that different cultures variably acted and reacted in different situations and chaotic changes on this planet. Thanks to social anthropology, different fundamental social ways of making sense of chaos were revealed and analyzed. Thus, the concept of the sacred changed meaning: it entered a new domain of sense-making accepting contradiction and reflexivity at the intersection of different knowledge fields.

In matters of sense-making, our footsteps are the road. Since the road is made by walking as we talk, anyone who dares to walk contributes to the path. In a society, we walk and talk together. Any society has to take a stand in relation to the universe, to nature, and to the interrelation of human beings. The sacred is the most fundamental organization of these relations. The sacred should neither be confused with religion nor transcendence. As the anthropologist Georges Balandier (1920-2016) put it, the sacred overflows the space of religions, it is independent of them, and the death of the gods does not entail its elimination. ${ }^{14}$ Whereas the sacred mostly deals with the perception of the

13 On the myth of the flood to be found in almost all societies, one can read E.J.M. Witzel, The Origins of the World's Mythologies, New York 2013, especially pp. 177-180, 348-355.

14 G. Balandier, Le désordre. Eloge du mouvement, Paris 1988, p. 233, my translation. 
limits of the human world, religion is maintaining formalized ways to deal with them. In other words, religion is what organizes the relationship to the sacred through rituals (for example, ceremonies and liturgies) and codes (for example, strictures and dogmas). Religion is a discourse (logos) about the sacred. Religion momentarily fills the void that the sacred as a perception and representation maintains open. ${ }^{15}$ Historically religious institutions had - for millennia - almost a monopoly on the management of the sacred. They lost this monopoly in modernity. The religious institutions have lost vitality, the problem has not. Philosophy and science to this day hold that The meaning of being is not to overcome its meaning. ${ }^{16}$

Nevertheless, in order to perceive itself and work upon itself, a society has to produce a representation of itself and create a distance to itself. ${ }^{17}$ This is paradoxical because society always produces a mirror to look at itself, and work upon itself, but - as already stressed above - it is this mirror that sees itself. Traditional societies did not relate to their myths as if they were their own products. In modernity the paradox has become obvious: individuals and society assume they remain in a relation of mutual transcendence towards each other. Nevertheless, the relation between the individual and the social, as well as across cultures, remains ambiguous even though autonomy and interrogation of the social emerge: as soon as the traditional religious points of reference are disclosed and disappear, the community gives itself new points of reference in order to put the social at a distance. It cannot be otherwise.

Still, the issue of what humans should tolerate and promote remains. The problem is that it has to be discussed within societies and cross-culturally. In today's globalized multicultural world, even individuals and cultures that intend to avoid the dialogue are confronted with it. In order to understand why and how the challenge of human societies facing chaos did change and why the issue of human rights should be taken seriously today, one must look into the different ways societies made sense, managed social change, and reacted to confrontations.

\section{CHALLENGED BY OTHERNESS}

Encounters and discoveries have always been interpreted. With the expansion of sources of information and of their interconnections, historians gave us new insights into what has been happening. For example, as mentioned earlier, the Greco-Roman past was rediscovered in the Renaissance. We can dig into how 'things' have changed. Thanks to historians, we know that Europe in the early Middle Ages was in a situation that was both unique and common. Like all human societies, it was egocentric, but its egocentricity

15 D. Bouchet, "Det hellige i sociologisk perspektiv", Paradigma, vol. 3, no. 4 (1989). Idem, "The Specificity of Human Aesthetics", Knowledge Cultures, vol. 3, no. 3 (2015).

16 J.-L. Nancy, The Sense of the World, transl. by J.S. Librett, Minneapolis 1998 [1993], back cover. Original: J.-L. Nancy, Le sens du monde. Édition revue et corrigée, Paris 2001.

17 D. Bouchet, "The Ambiguity of Modern Conception of Autonomy and the Paradox of Culture", Thesis Eleven, vol. 88, no. 1 (2007), p. 48. 
was not only mystical or symbolic: it rested on foundations assumed to be strong and that seemed to respond to demonstrable evidence. ${ }^{18}$ In the Middle Ages explorers had above all to discover what they believed in. ${ }^{19}$ The denial of otherness was a form of reduplication. ${ }^{20}$ As with goods, there was no border for religions. They all felt a universal vocation, wanted to be heard everywhere. ${ }^{21}$ Thus, medieval travelers were not able to identify with the various doctrines and saw little difference between them. (...) Not-belonging to Christianity was the essential criterion. ${ }^{22}$ Still, the discovery of the human masses of Asia and of the religions they professed made it necessary to wonder about the place of Europeans and of Christianity in the universe.

These two tough questions took precedence over all the others, both immediately and in the future, through the consideration that they sparked. 'We Christians are not the tenth, not the twentieth part of humanity.' This observation of the Directorium called everything into question..$^{23}$ When confronted with a broader view of the world, Christianity felt weakened, less dignified and mighty. Nevertheless, what never ceased to interest them, from the first voyage to the last, was the creatures inhabiting the world: men and the beings they had never met but believed they existed, the monster-figments offable and myth. Those haunt the imagination in the Middle Ages; in the vast repertoire of Roman or Gothic sculptures, they hold a place just as natural as the characters of Holy Scriptures. To people, they are nothing more than reflections of their own selves. Thus, through both kinds [mythologies and ethnographies], they bring everything back to themselves, show a total egocentricity that probably is a memory of cosmic symbolism and which they will never give up along the way. (...) The interest they showed for the things they discovered was not for the value they could have as such: it was to bring them back to their own vision, to their concepts, that is to say, fundamentally to themselves. How, then, can we be surprised that everything they have done, everything they have known constantly gives us the impression of only to have had interest in relation to themselves? $?^{24}$ It does not mean that the Other is of no interest at all; it means that the way to look at otherness is totally self-centered, and, as it is an epoch when God is not debatable, but imposed by faith, by revelation, and if necessary, by sword and fire, ${ }^{25}$ universal rights were inconceivable.

The Directorium inquisitorum mentioned above was signed in 1376 by the Dominican inquisitor Nicolau Eymerich in the papal court in Avignon. At the time the discussions concerning who belonged and behaved rightly concerned only people the church knew about. Other windows to the world and mirrors for the conquerors

18 J.-P. Roux, Les explorateurs au Moyen-Âge, Paris 1995, p. 20, my translation.

19

20 pp. 31-32.

21

22

23

24

25

Ibid., p. 137, my translation.

F. Affergan, Exotisme et altérité. Essai sur les fondements d'une critique de l'anthropologie, Paris 1987,

J.-P. Roux, Les explorateurs..., p. 33, my translation.

Ibid., p. 241, my translation.

Ibid., p. 234, my translation.

Ibid., pp. 252-253, my translation.

Ibid., p. 239, my translation. 
would appear soon, though. On Friday morning October 12, 1492, for the first time in the history of the West men never previously seen were discovered. Yet, the first and almost unique descriptor of the perceived human reality will be nudity. ${ }^{26}$ Even and especially if the Other is monstrous and bestial, he is still worthy of the greatest observational interest. One condemns, but this does not prevent one from describing in great detail. These two edges of the same medieval otherness will be found in both original myths to which the New World will give birth: the Good Savage and the Monstrous Savage. This epistemic and affective ambivalence will run in almost all the accounts of discovery. ${ }^{27}$ The issue for those in charge of evaluating what was right for whom at the time in that part of the world was first of all to identify who was to receive the word of God and who was to serve as a slave.

Another Dominican, Bartolomé de Las Casas, argued that everyone was legally obligated to prevent the mistreatment of innocent people. A willing participant in the conquest of America from 1502, he had been given an encomienda - a royal land grant including Indian inhabitants - and had evangelized that population. He had received the holy orders and an allotment of Indian serfs. But he ended up feeling the necessity to defend the rights of the indigenous peoples. On August 15, 1514, he announced in a sermon that he was returning his Indian serfs to the governor. Back in Spain he studied the juridical problems of the Indies and acted politically to defend the rights of the Indians. In his writings, he accused persons and institutions of the sin of oppressing the Indian, particularly through the encomienda system. He pointed out that the reason why the Christians have killed and destroyed so infinite a number of souls is that they have been motivated by their wish for gold and their desire to enrich themselves in a very short time. ${ }^{28}$ Las Casas wrote books and letters describing what he had seen and what he considered right and tried to have an impact on the legal and theological powers. His masterpiece is the Historia de las Indias. He ended up being an influential figure at the court of the emperor Carlos $\mathrm{V}$ and at the Council of the Indies. When the Valladolid debate took place in $1550,{ }^{29}$ Las Casas had to confront another important figure at court, the learned Juan Ginés de Sepúlveda, by reason of his Concerning the Just Cause of the War Against the Indians, in which Sepúlveda maintained, supposedly in accordance with Aristotelian principles, that the Indians are inferior to the Spaniards just as children are to adults, women to men, and, indeed, one might even say, as apes are to men..$^{30}$ Las Casas defended the rights of the native Indians referring to the works of Saint Augustine and Saint John Chrysostom ( 354-407), who both opposed forced conversions to Christianity.

26 F. Affergan, Exotisme et altérité, p. 67, my translation.

27 Ibid., p. 66, my translation.

28 B. de Las Casas, Très brève relation de la destruction des Indes, Paris 1979 [1542].

29 One can watch the instructive movie The Controversy of Valladolid: J.-C. Carrière, J.-D. Verhaeghe, La controverse de Valladolid, Paris 1992.

30 J. Ginés de Sepúlveda, Democrates segundo o De las justas causas de la guerra contra los indios, Madrid 1984. 
As I will need to come back to this at the end of this text referring to human rights, let me stress that Augustine (354-430), just as Las Casas (1474-1566), lived in troubled times and they were both trying to figure out what was right and wrong, albeit in different global and local contexts. Augustine was the shaper of the Western Church in a collapsing world. His life played out against the background of the rise, final splendor, and fall of the Christian Western Empire. In 412, Augustine had expressed that a Christian government had the duty to support the Church by punishing heresy and schism, and the unwilling adherence which this produced might be the start of a living faith. Augustine referred to a parable of Jesus in which a host had filled up places at his banquet with an order, 'Compel them to come in.' This was a side of Augustine's teaching which had much appeal to Christian regimes for centuries to come. Las Casas insisted that Augustine's gloss on the biblical text 'Compel them to come in' was wrong: Jesus had not intended conversion to his 'joyful tidings' to be a matter of 'arms and bombardments' but of 'reason and human persuasion. ${ }^{31}$ This is an issue of legitimacy. The point I will make at the end is that we should try to think about how Augustine and Las Casas would argue if they were facing the troubles of our time. ${ }^{32}$

Las Casas was the first to expose the oppression of indigenous peoples by Europeans in the Americas and to call for the abolition of slavery there. Still, the servitude

31 D. MacCulloch, A History of Christianity. The First Three Thousand Years, London 2010, p. 692.

32 In his twelve hundred pages masterclass of a history book about the history of Christianity, Diarmaid MacCulloch, Professor of the History of the Church at Oxford University, explains that Augustine's life's work can be seen as a series of responses to conflicts, both internal and external. The first struggle was with himself. Who did he want to be and how would he find a truth which would satisfy him? (...) What was the source of evil and suffering in this world? (...) He was haunted by doubts and anxieties about the nature of truth, reality and wisdom. (...) Augustine found in conversion a liberation from torment (... then) his plan was to create a celibate religious community with cultivated friends back in his home town: a monastery that bring the best of Roman culture of old Rome into a Christian context. (...) In 391 Augustine happened to visit the struggling Catholic congregation in the city of Hippo Regius (now Annaba in Algeria), (...) All his theological writing was now done against a background of busy pastoral work and preaching for a Church in a world in collapse (...) The next period in his life was dominated by the problem posed by the Donatists, in terms not just of politics but also of the challenges that their theology posed to the Catholics. Proud of their unblemished record intime of persecution, [the Donatists] proclaimed that the Church was a gathered pure community. Augustine thought that this was not what 'One, Holy and Catholic' meant. The Catholic Church was a Church not so much of the pure as those who tried or longed to be pure. Unlike the Donatists, it was in communion with a great mass of Christian communities throughout the known world. The Catholic Church was in fact what Angustine was not afraid to call 'the communion of the emperor' (...).By 412 Augustine had lost patience and he backed harsh new government measures against the Donatists. He even provided theological reasons for the repression: he pointed out to one of his Donatist friends that Jesus had told a parable in which a host had filled up places at his banquet with an order, 'Compel them to come in.' That meant that a Christian government had the duty to support the Church by punishing heresy and schism, and the unwilling adherence which this produced might be the start of a living faith. This was a side of Augustine's teaching which had much appeal to Christian regimes for centuries to come. D. MacCulloch, A History of Christianity..., pp. 301-304. Las Casas insisted that Augustine of Hippo's gloss on the biblical text 'Compel them to come in' was simply wrong: Jesus had not intended conversion to his 'joyful tidings' to be a matter of 'arms and bombardments' but of 'reason and human persuasion.' Ibid., p. 692. 
of the Indians was already established and, although they had not been officially approved, Sepúlveda's teachings were followed. Nevertheless, Las Casas kept on writing arguments, testimonies, and petitions to advance the cause of the indigenous peoples of the Americas. The purpose of all the facts he sets forth is the exposure of the sin of domination, oppression, and injustice that the European was inflicting upon the newly discovered peoples. It was Las Casas's intention to reveal to Spain the reason for the misfortune that would inevitably befall it when it became the object of God's punishment. ${ }^{33}$ It is of course interesting to note the use of the concepts of sin and soul in Las Casas political argumentation, as well as his reference to the fundament of the truth. Thus, in 1559 he had left written instructions that his work Prólogo to the Historia de las Indias (which was published in 1562) should be published only after forty years have passed, so that, if God determines to destroy Spain, it may be seen that it is because of the destruction that we have wrought in the Indies and His just reason for it may be clearly evident..$^{34}$

The modern significance of Las Casas lies in the fact that he was the first European to perceive the economic, political, and cultural injustice of the colonial or neocolonial system maintained by the North Atlantic powers since the $16^{\text {th }}$ century for the control of Latin America, Africa, and Asia. ${ }^{35}$ Still, it is also significant for us today that Las Casas warned about a possible punishment from God, but did not think much about the economic, political, and cultural consequences of colonization. His writings about Spanish barbarity in America became part of the general Protestant stereotype of Spaniards as a naturally cruel race.

Las Casas died in 1566. In the same period Calvin (1509-1564) maintained that the social order must be respected however unjust it might seem because no right of the weak over the strong could be inferred from Christian fraternity: We are brothers, but that does not prevent one from being a master and the other servant (...) because this sacred union that he [God] has put between us - I say of fraternity - does not prevent that there is one inferior and the other superior. That in such condition that God call us, we must remain peaceful. ${ }^{36}$

A few years later, in the middle of the wars of religion between Protestants and Roman Catholics in France, Michel de Montaigne would write: Every man calls barbarous anything he is not accustomed to. It is indeed the case that we have no other criterion of truth or right-reason than the example and form of the opinions and customs of our own

33 E. Dussel, "Bartolomé de Las Casas. Spanish Historian and Missionary", in Encyclopedia Britannica, p. 685, at <https://www.britannica.com/biography/Bartolome-de-Las-Casas>, 2 March 2021.

34 Quote found in: ibid., p. 685.

35 Ibid., p. 686.

36 Own tranlation of Nous sommes frères, mais cela n'empêche pas que l'un soit maître et l'autre valet (...) car cette union sacrée qu'il [Dieu] a mise entre nous - je dis de fraternité - cela n'empêche pas qu'il y en ait l'un inférieur et l'autre supérieur. Qu'il faut qu'en telle condition que Dieu nous appelle, nous demeurions paisibles. J. Calvin, "Sermon XLVI sur la Première Épitre à Timothée”, Chapitre 6, in Sermons de Jean Calvin sur les deux Epistres Saint Paul à Timothée \& sur l’Epistre à Tite [Jean Bonnefoy 1563], Genève, p. 277. Found in: A. Supiot, La force d'une idée. Suivi de l'idée de justice sociale d'Alfred Fouillée, [Paris] 2019, p. 18. 
country. There we always find the perfect religion, the perfect polity, the most developed and perfect way of doing anything! ${ }^{37}$

It is worth mentioning, though, that at one stage Las Casas suggested a fateful remedy for the exploitation of native labor in America: African slaves should be imported to replace natives on plantations, radically extending the slave trade which the Portuguese had pioneered in the previous century. Las Casas eventually realized his mistake, but it was too late. Here idealism trying to end one injustice blundered unhappily into colluding with a genocidal crime of three centuries' duration, whose consequences are still built into the politics of both Americas. ${ }^{38}$

Slavery is essentially the expression of non-respect of the other precisely because this other is perceived as not worthy of such a respect as he does not belong to the group in power. The criteria used for the evaluation of what makes a difference and what is right varied in space and time in relation to how the groups managed their internal and external relations.

We must remember that slavery was a fundamental institution in ancient society and that the coming of Christianity made little significant difference to the position of slaves. In the early $2^{\text {nd }}$ century, when the Church's leadership was beginning to be concentrated in the hands of single individuals styled bishops, Bishop Ignatius of Antioch observed in a letter to his fellow Bishop Polycarp of Smyrna that slaves should not take advantage of their membership in the Christian community, but live as better slaves, now to the glory of God - and his opinion was that it would be inappropriate to use church funds to help slaves buy their freedom..$^{39}$ And by the $4^{\text {th }}$ century, Christian writers like Bishop Ambrose of Milan or Bishop Augustine of Hippo were providing even more robust defenses of the idea of slavery than non-Christian philosophers had done before them'the lower the station in life, the more exalted the virtue,' was Ambrose's rather unctuous opinion. ${ }^{40}$

Today, four centuries after Montaigne, we can stress that such self-centered cultural contempt, arrogance, and scorn cannot be justified by the argument of living in noncommunicable worlds. Thanks to interdisciplinary scientific knowledge, we know that it is the expression of a refusal to communicate not only with others but also with oneself. Human indifference is today evidently more cultural in nature because the representation of intentions became obviously more possible for humans. The ethologist, neurologist, psychiatrist, and psychoanalyst Boris Cyrulnik points out, our species is the one that has the greatest access to the 'theory of others,' the ways in which others represent

37 M. de Montaigne, The Complete Essays, transl. and ed. with an introduction and notes by M.A. Screech, Harmondsworth 2003 [1580-1588], p. 231. Original: M. de Montaigne, Les Essais Livre II. Édition critique d'André Tournon, Paris 1998 [1580], pp. 343-344 or idem, Les Essais. Édition établie par Jean Balsamo, Michel Magnien et Catherine Magnien-Simoni, Paris 2007 [1580-88], p. 203 or idem, Essais. Tome I. Edition de Maurice Rat, Paris 1962, p. 234

D. MacCulloch, A History of Christianity..., p. 692.

39 Ibid., p. 116.

Ibid. 
reality; [and that] violence arises, then, from intolerance, i. e. from the in ability to step outside one's own set of interpretations of the world. ${ }^{41}$

When the Pope and the emperor Carlos V were confronted with such great cultural differences in their relation to the Indians, they had to interpret and manage them based on the knowledge and understanding at their disposal at the time. No wonder, the way to address the issue of human rights evolved in relation to experiences and challenges within the system of power.

\section{BOUND TO MAKE DISTINCTIONS AND UPDATE BOUNDARIES}

At the times when indigenous peoples from Amazonia and Australia had not yet been confronted by conquering empires, their ways of making sense and relating to their environment were much different from the people they suddenly had to relate to when colonization took place. Thanks to anthropology, we know that many tribes felt obliged to pay respect to certain species that in Europe were considered simple things that could be disposed with. Thanks to palaeoanthropology, we realized that also in Europe thirty thousand years ago humans seemed to be impressed by the animals they killed to eat. Clearly, humans have not always and everywhere considered themselves so special and above all other creatures on earth. Still, humans everywhere made sense of what they did and who they were, and thus made choices regarding right and wrong. It is through culture patterns, ordered clusters of significant symbols, that man makes sense of the events through which he lives. The study of culture, the accumulated totality of such patterns, is thus the study of the machinery individuals and groups of individuals employ to orient themselves in a world otherwise opaque. ${ }^{42}$

Even historians and philosophers like Las Casas and Montaigne were at the time not able to study more carefully the way cultures that did not have an understanding of themselves as being above every other creature on the Earth made sense of the other. As mentioned, the attention of conquerors focused on what mattered to them and thus not necessarily on being challenged in their way of making sense. Today many Europeans are still amazed that in China it is common to eat snakes, cats, and dogs, and they do not link this with the fact that it took hundreds of years for the part of Europe where they live and eat today to be marked by the culinary customs arising from the commandments of the Bible.

Anthropologists such as Claude Lévi-Strauss, Mary Douglas, and Jean Soler have demonstrated that interdictions and interpretations regarding animals are linked to established symbolic systems. The latter two thinkers have delved deeply into the origins of dietary customs arising from their codification at the time of the Old Testament. This was carried out on the basis of the theories of classification and observation at the time when monotheism emerged: These are the living things which you may eat among

41 B. Cyrulnik, Les nourritures affectives, Paris 1993, pp. 112-113, my translation.

42 C. Geertz, The Interpretation of Cultures, New York 1973, p. 363. 
all the beasts there are on earth (Leviticus XI.2). ${ }^{43}$ During this period the differences that Man observed in Nature were not random. Rather, they manifested the will of the Creator. To respect them is a religious duty and, even more, the condition for the maintenance of the pact that guarantees the Israelites the protection of the Almighty. At this level the sacred and the profane are inextricably intertwined. Dietary rules are as important as religious ones. All social activities are fixed within a network of obligations and interdictions that the Bible bases on the Sinai revelation and which corresponds to a unique phenomenon: the Law. ${ }^{44}$ In order for Man to eat an animal that animal must respect its position laid down in the Creation plan and Man's way offeeding himself must not disturb that order. ${ }^{45}$ In different times and places different cultures adhered to different codes of conduct.

Neither did cattle nor agriculture nor science make sense in the Old Testament days. In the Old Testament it reads: I will unleash the animal of the fields against you and it will deprive you of children, it will exterminate your cattle (Leviticus, XXVI, 22). Las Casas was not aware that, precisely because Europeans raised, and lived next to, cows while Amerindians did not, his presence may cause more death of indigenous peoples than his guns. ${ }^{46} \mathrm{Had}$ he known about this gained virus immunity, Sepúlveda might have interpreted it as the proof that he was right to discriminate the way he did.

The use of knowledge and interpretation systems evolved with life conditions and political challenges. References change and the relation between the remains of beliefs and modified practices do not necessarily go along with the original motives and arguments. As already mentioned, during the times when the Pope and the King had to figure out whether the oppression of these indigenous peoples they had not read about in the Bible was legitimate, Sepúlveda justified the war of conquest by the Aristotelian idea of natural servitude, whereas Las Casas referred to Saint Augustine's opposition to forced conversions to Christianity.

Today, as/when information about customs and conditions of life around the world is disclosed and updated so easily, the issue of what is an appropriate behavior toward

43 Leviticus XI.2 in M. Douglas, Purity and Danger, London 1970, p. 55.

44 J. Soler, "Les raisons de la Bible: règles alimentaires hébraïques", in J.-L. Flandrin, M. Montanari (ed.), Histoire de l'alimentation, Paris 1996, p. 78.

45 Ibid., p. 79.

46 From Bartolomé de Las Casas on, Europeans have known that their arrival brought about a catastrophe for Native Americans. "We, Christians, have destroyed so many kingdoms," reflected Pedro Cieza de Leon, the traveler in postconquest Peru. "For wherever the Spaniards have passed, conquering and discovering, it is as though a fire had gone, destroying every-thing in its path." And since Las Casas historians, clerics, and political activists have debated whether Europeans and their descendants in the Americas are morally culpable for the enormous Indian losses. Indeed, some writers have employed the loaded term 'holocaust' to describe the contact and its aftermath. Following in its train, inevitably, has come an even more potent label: genocide. Ch.C. Mann, 1491. The Americas before Columbus, New York 2005, p. 129. 'Sickness was the physical manifestation of the will of God,' Robert Crease, a philosopher of science at the State University of New York at Stony Brook, told me. 'You could pass it on to some-one, but doing that was like passing on evil, or bad luck, or a bad spirit - the transmission also reflected God's will.' The conquistadors knew the potential impact of disease, but its actual impact, which they could not control, was in the hands of God. Ibid., p. 131. 
others is still addressed. References are still made to cultural heritage with the same difficulties and discrepancies.

In October 2020, speaking to the population of the whole world, a prominent opinion leader declared: We cannot be indifferent to suffering; we cannot allow anyone to go through life as an outcast. Instead, we should feel indignant, challenged to emerge from our comfortable isolation and to be changed by our contact with human suffering. That is the meaning of dignity. Those words are to be found in Pope Francis' encyclical Fratelli Tut$t i{ }^{47}$ In its chapter two, the current Pope of the Catholic Church refers to the parable of the Good Samaritan which became part of the common good in a large part of the world. The parable originally built upon traditions and rules specific to a particular local culture, and the Pope does mention it: In earlier Jewish traditions, the imperative to love and care for others appears to have been limited to relationships between members of the same nation. The ancient commandment to love your neighbor as yourself (Lev 19:18) was usually understood as referring to one's fellow citizens. ${ }^{48}$ Pope Francis does refer to the fact that the wounded man was a Judean, while the one who stopped and helped him was a Samaritan. This detail is quite significant for our reflection on a love that includes everyone. The Samaritans lived in a region where pagan rites were practiced. For the Jews, this made the people impure, detestable, dangerous. In fact, one ancient Jewish text referring to nations that were hated, speaks of Samaria as not even a people (Sir 50:25); it also refers to the foolish people that live in Shechem (Sir 50:26). ${ }^{49}$

Still, as he refers to these local historical facts and texts, Pope Francis sifts out and updates them, so they fit his present-day global ideological purpose. Here is his updated version: Jesus tells the story of a man assaulted by thieves and lying injured on the wayside. Several persons passed him by, but failed to stop. These were people holding important social positions, yet lacking in real concern for the common good. They would not waste a couple of minutes caring for the injured man, or even in calling for help. Only one person stopped, approached the man and cared for him personally, even spending his own money to provide for his needs. He also gave him something that in our frenetic world we cling to tightly: he gave him his time. Certainly, he had his own plans for that day, his own needs, commitments and desires. Yet he was able to put all that aside when confronted with someone in need. Without even knowing the injured man, he saw him as deserving of his time and attention. ${ }^{50} \mathrm{How}-$ ever, in the context of the time the reason why those two people holding important social positions did not help the unfortunate was not because they felt their own time was so precious and did not care for other people needs. Claiming that they were lacking real concern for the common good assumes that the concept made sense to them at the time. It did not. They were not concerned with the common good but with their community's rules and their personal duties. Human rights did not make sense then. That priest and that Levite

47 Pope Francis, Fratelli Tutti, no. 68, at <https://www.vatican.va/content/francesco/en/encyclicals/documents/papa-francesco_20201003_enciclica-fratelli-tutti.html>, 2 March 2021.

48 Ibid., no. 59.

49 Ibid., no. 82 .

50 Ibid., no. 63 . 
were bound by their 'local' sectarian law of purity. Nowadays such a law is mostly odious, ludicrous, or unintelligible over the globe. The priest and the Levite are not 'important' people without a heart. What was important to them was their God, and they loved God with all their heart with a love inseparable from obedience to the Law.

The priest could not defile himself by touching a corpse, or someone 'half-dead' who might indeed be dead in a moment. In Leviticus it reads: Yahweh said to Moses, speak to the priests, the children of Aaron, and say to them: None of them shall be unclean near the body of any of his own, except for his closest relatives. ${ }^{51}$ The Levite's duty is also to respect the purity law. In the Pentateuch $4^{\text {th }}$ book it reads: "He that touches the dead body of any man shall be unclean for seven days. (...) Whoever touches a dead man, the body of any man that is dead, and purifies not himself, defiles the tabernacle of the Lord, and that soul shall be cut off from Israel: because the water of separation was not sprinkled on him, he shall be unclean; his uncleanness is yet on him. (...) But the man that shall be unclean, and shall not purify himself, that soul shall be cut off from among the congregation, because he has defiled the sanctuary of the Lord. ${ }^{52}$

Thus, at that time the parable was a proposal for a reform of the Jews' old rules and for an obliteration of their demarcations. However, this broadening of the community and reforming of the rules was still inscribed in a local and transcendent logic. It did not necessarily question the status of poor others and slaves. It did not refer to the common good, but only to the proper behavior of the members of the community. It did not mention the rights of all others but the duty of members. It did not refer to the community from within but to the Lord above and to the community below. It did not provide universal principles for individuals and groups to manage respectful relations with each other. Thus, it cannot really be compared to later discourses referring to nations and people of the world. Referring to such a parable without reference to its historical context amounts to support an ideology rather than an analysis. ${ }^{53}$ This call to care for human suffering comes with a promotion of a specific form of authority. As if it

51 Leviticus XXI,1.

52 Pentateuch $4^{\text {th }}$ book, no. 11, 13.

53 The parable of the 'Good Samaritan' has been used for many centuries and interpreted in different historical contexts. Outside and within the community of believers some people found it legitimate whether the motivation of someone pretending to act like the 'Good Samaritan' was to gain God's attention, spare some time in the purgatory, help the other for the other's own sake or for the sake of the common good, to gain attention and enjoy esteem from his fellow citizens or friends. The reference to the issue of bloody wounds and their perception two thousand years ago seems to have lost relevance for others than historians who, as historians, precisely are more interested in contextual analysis than in ideological use. For scientists it is important to notice and interpret historical changes such as those safety rules, implicitly mentioned in the parable, promoted by a specific community at a specific time concerning what to eat, touch, and avoid at a time when scientific knowledge was absent and prejudice common. Scientists intend to minimize the influence of the ideologies of their time to read and interpret what becomes observable. Thus, when in December 1994 the incredibly well painted scenes of animals were discovered in the 36000 years old caves Chauvet at Pont d'Arc in France, scientists did not just refer to one single text or one single school of thoughts. They secured transdisciplinary links that could provide explanations and dared to challenge former statements within those many disciplines. A. Testart, Art et religion de Chauvet à Lascaux, Paris 2016; J. Clottes (ed.), La grotte Chauvet: 
goes without saying, it perpetuates a local historical specific ethical model based on the submission to a transcendental law imposing duties. Still, the form and scope of this imposition did evolve through the many interpretations in relation to historical challenges; and every time depending on the nature of the links established between different powers that had their say. When the Christian religion instituted a new universal community, the church to which all people are potentially attached, a new political problem arose. It introduced a political ambiguity, and a new political problem arose. On the one hand, Christianity liberated a secular space, because unlike the synagogue, the Church did not impose political laws, it even stated that political communities could organize themselves as they wanted. On the other hand, the Church weakens the legitimacy of the ruling political communities by referring to the sacred principle of charity. Thus, the Church competes with the local units of power because it speaks directly and from above the individual to offer her or him an overall affiliation with the good community, which differs from other communities by being perfect and universal. Still this universality was not a political right but a religious duty.

The two pre-existing forms of community at the time - the city and the empire were challenged, and the question of the distribution of power took on a new dimension. The Roman empire managed to make use of the Church in the $4^{\text {th }}$ century.

By the way, the issue of whether Constantine the Great ( 285-337) converted for religious or political reason also has to be addressed in its historical context. At the time, atheism, rationalism, and indifferentism could not be considered; in other words, they were not among the philosophical attitudes. Later in history, a crucial stage of this controversy was the investment dispute between the pope and the emperor, which took place in the middle of the $11^{\text {th }}$ century. ${ }^{54}$ For at least a thousand years, European history has been marked by the relationship between religious and political institutions, and philosophers came up with different analysis of this relationship and consequences for the common good. Jean-Jacques Rousseau wrote in 1762: What the pagans had feared came to pass, everything then changed in appearance, the humble Christians changed their language, and before long this supposedly other-worldly kingdom was seen to become under a visible chief the most violent despotism in this world. However, since there has always been a Prince and civil laws, this dual power has resulted in a perpetual conflict of jurisdiction which has made any good polity impossible in Christian States, and no one has ever succeeded in settling the question of which of the two, the master or the priest, one is obliged to obey. ${ }^{55}$

L'art des origines, Paris 2010; D. Bouchet, "The Innovative Role of Art in the Time of the Absence of the Myth", Chapter 9, in P. Murphy, E. de la Fuente (eds.), Aesthetic Capitalism, Leiden 2014.

54 The start of the investment dispute is usually set at 1059 and is considered to end in 1122 with the Worm Concordat, but can be said to have continued to our times as it had great significance for the Reformation. Political collaboration was also experienced: the pope of Rome for instance provided specific rights/privileges to the king of Spain in 1493 and the king of England declared in 1534 that he alone should be the final authority in matters relating to the English Church.

55 J.-J. Rousseau, The Social Contract and Other Later Political Writings, ed. and transl. by V. Gourevitch, Cambridge 1997, p. 145. Original: J.-J. Rousseau, Du contrat social ou principes du droit politique, Paris 1962 [1762], p. 329, pp. 145, 329. 
Through history the issue of how to relate internally and externally to the different powers at stake evolved with imperialistic expansions and confrontations, religious wars between religions and wars between states. All this impacted on the way people disposed of political power, belonged to religious orders, tried to make sense or produce knowledge, (philosophers, scientists, historians) interpreted and communicated. Social interactions, international relations and socialization processes involve much different forms of perceptions and much more varied knowledge fields than ever. Societies, citizens, the economy, the market, international institutions, technologies do not really compare to what they were in the time of Constantine the Great or Las Casas. Still, suffering and slavery continue to be experienced in different ways and by an even larger number of human beings today than at the times of Constantine, Augustin, and Las Casas.

Many people around the globe are most likely to agree today with the statement: We cannot be indifferent to suffering; we cannot allow anyone to go through life as an outcast. Actually, this is pretty close to a declaration in favor of the universality of human rights. But these words of Pope Francis are immediately followed by Instead, we should feel indignant, challenged to emerge from our comfortable isolation and to be changed by our contact with human suffering. That is the meaning of dignity. ${ }^{56}$ Thus, Pope Francis emphasizes the importance of our feelings (we cannot be indifferent [...] we should feel indignant) and promotes the personal benefit individuals can get ([being] changed by [their] contact with human suffering). Thus, the imperative to love and care for others focuses on the duty for those who feel they must express their love and membership, not on the legitimacy of other's claim for their rights and dues. The emphasis is not on what the other deserves regardless of the community she or he belongs to, but on what oneself can achieve by paying one's dues to the community one belongs to. This call for care has not much to do with human rights as the motivation for this love and care has still to come from above. It does not introduce a general code of behavior to break the old rules and broaden the local community.

Again, historians have shown that the interpretation and use of the religious texts varied in relation to challenges, interactions, and confrontations of the time. In Fratelli Tutti Pope Francis chose to focus on the possibility to rebuild a community and to reject the creation of a society of exclusion. Pope John Paul II in Veritatis Splendor focused on the necessity to submit to the universal and objective norm of morality, which, being a moral truth revealed by Christ, compels recognition by all and cannot be derived from cultures or history or from any autonomy of man or reason. He admonishes moral theologians to exercise careful discernment in the context of today's prevalently scientific and technical culture, exposed as it is to the dangers of relativism, pragmatism and positivism. ${ }^{57}$ John Paul II strengthens believer's duty to rely on the moral norms taught by the Church and to feel sorry for those who do not. But, in contrast to Pope Francis, he does

\footnotetext{
56 Pope Francis, Fratelli Tutti, no. 68.

57 John Paul II, Veritatis Splendor, no. 112, at <https://www.vatican.va/content/john-paul-ii/en/encyclicals/documents/hf_jp-ii_enc_06081993_veritatis-splendor.html>, 2 March 2021.
} 
not react much to the challenges of lifting up and rehabilitating the fallen for the sake of the common good. ${ }^{8}$ Obviously, John Paul II is more concerned with the submission to the truth indicated by the divine law than with the changing condition of man.99

58 Pope Francis, Fratelli Tutti, no. 67. To illustrate the contrast between the two popes, let me quote more of Pope Francis' words: "We need to acknowledge that we are constantly tempted to ignore others, especially the weak. Let us admit that, for all the progress we have made, we are still 'illiterate' when it comes to accompanying, caring for and supporting the most frail and vulnerable members of our developed societies (ibid., no. 64). (...) In the face of so much pain and suffering, our only course is to imitate the Good Samaritan (...) The parable shows us how a community can be rebuilt by men and women who identify with the vulnerability of others, who reject the creation of a society of exclusion, and act instead as neighbours, lifting up and rehabilitating the fallen for the sake of the common good (ibid., no. 67). (...) So this encounter of mercy between a Samaritan and a Jew is highly provocative; it leaves no room for ideological manipulation and challenges us to expand our frontiers. It gives a universal dimension to our call to love, one that transcends all prejudices, all historical and cultural barriers, all petty interests (ibid., no. 83).

59 The theme of submission to a universal truth revealed from above, transmitted by the Church alone is voiced in the following sections of Pope John Paul II Veritatis Splendor promulgated on 6 August 1993:

no. 60: Like the natural law itself and all practical knowledge, the judgment of conscience also has an imperative character: man must act in accordance with it. If man acts against this judgment or, in a case where he lacks certainty about the rightness and goodness of a determined act, still performs that act, he stands condemned by his own conscience, the proximate norm of personal morality. The dignity of this rational forum and the authority of its voice and judgments derive from the truth about moral good and evil, which it is called to listen to and to express. This truth is indicated by the 'divine law', the universal and objective norm of morality. The judgment of conscience does not establish the law; rather it bears witness to the authority of the natural law and of the practical reason with reference to the supreme good, whose attractiveness the human person perceives and whose commandments he accepts. Conscience is not an independent and exclusive capacity to decide what is good and what is evil. Rather there is profoundly imprinted upon it a principle of obedience vis-a-vis the objective norm which establishes and conditions the correspondence of its decisions with the commands and prohibitions which are at the basis of human behaviour (John Paul II, Veritatis Splendor, no. 60).

no. 88: The attempt to set freedom in opposition to truth, and indeed to separate them radically, is the consequence, manifestation and consummation of another more serious and destructive dichotomy, that which separates faith from morality. This separation represents one of the most acute pastoral concerns of the Church amid today's growing secularism, wherein many, indeed too many, people think and live 'as if God did not exist.' We are speaking of a mentality which affects, often in a profound, extensive and allembracing way, even the attitudes and behavior of Christians, whose faith is weakened and loses its character as a new and original criterion for thinking and acting in personal, family and social life. In a widely dechristianized culture, the criteria employed by believers themselves in making judgments and decisions often appear extraneous or even contrary to those of the Gospel.

It is urgent then that Christians should rediscover the newness of the faith and its power to judge a prevalent and all-intrusive culture. (...)

It is urgent to rediscover and to set forth once more the authentic reality of the Christian faith, which is not simply a set of propositions to be accepted with intellectual assent. Rather, faith is a lived knowledge of Christ, a living remembrance of his commandments, and a truth to be lived out. (...) It entails an act of trusting abandonment to Christ, which enables us to live as he lived (cf. Gal 2:20), in profound love of God and of our brothers and sisters (ibid., no. 88). (...)

no. 96: The Church's firmness in defending the universal and unchanging moral norms is not demeaning at all. Its only purpose is to serve man's true freedom. Because there can be no freedom apart from or in opposition to the truth, the categorical - unyielding and uncompromising - defense of the absolutely essential demands of man's personal dignity must be considered the way and the condition for the very existence offreedom (ibid., no. 96). (...) 


\section{DISCUSSING THE VALUE OF TRUTH IN COMMAND}

In his brilliant Treatise On the Great Virtues. The Uses of Philosophy In Everyday Life, André Comte-Sponville exposes the logic and consequences of such a dogmatic tale: Truth compels recognition by all; therefore so does religion (since it is the true religion) and so does morality (since it is 'founded upon truth') This philosophy is like a Russian doll: one must obey the truth, therefore God, therefore the Church, therefore the pope. ${ }^{60}$ And the philosopher makes a link with the Stalinian rhetoric: If truth commands, as Plato, Stalin, or Jean-Paul II believes, then the only virtue is submission to truth. ${ }^{61}$

Nevertheless, different interpretations and uses of dogmas have been promoted, and in conflict for thousands of years. Historical research has made it obvious and it is part of the common good today. The foundation and preservation of power structures have never relied on dogmas alone: they have always been acted upon by internal and external challenges of many kinds: epidemics, conquests, invasions, starvation, education, competition, etc. Historically it has never been possible for any dogmatic organization to maintain forever its interpretation and control, either internally or externally. Social sciences demonstrated that there is no society, institution, or organization untouched by social change. Historians have documented the many developments locally and globally.

no. 101: Thus, in every sphere of personal, family, social and political life, morality - founded upon truth and open in truth to authentic freedom - renders a primordial, indispensable and immensely valuable service not only for the individual person and his growth in the good, but also for society and its genuine development (ibid., no. 101). (...)

no. 106: Today's widespread tendencies towards subjectivism, utilitarianism and relativism appear not merely as pragmatic attitudes or patterns of behaviour, but rather as approaches having a basis in theory and claiming full cultural and social legitimacy (ibid., no. 106). (...)

no. 112: The moral theologian must therefore exercise careful discernment in the context of today's prevalently scientific and technical culture, exposed as it is to the dangers of relativism, pragmatism and positivism. From the theological viewpoint, moral principles are not dependent upon the historical moment in which they are discovered. Moreover, the fact that some believers act without following the teachings of the Magisterium, or erroneously consider as morally correct a kind of behavior declared by their Pastors as contrary to the law of God, cannot be a valid argument for rejecting the truth of the moral norms taught by the Church. The affirmation of moral principles is not within the competence of formal empirical methods. While not denying the validity of such methods, but at the same time not restricting its viewpoint to them, moral theology, faithful to the supernatural sense of the faith, takes into account first and foremost the spiritual dimension of the human heart and its vocation to divine love (ibid., no. 112). (...)

no. 117 When people ask the Church the questions raised by their consciences, when the faithful in the Church turn to their Bishops and Pastors, the Church's reply contains the voice of Jesus Christ, the voice of the truth about good and evil. In the words spoken by the Church there resounds, in people's inmost being, the voice of God who 'alone is good' (cf. Mt 19:17), who alone 'is love' (1 Jn 4:8, 16). (ibid., no. 117).

60 A. Comte-Sponville, A Short Treatise on the Great Virtues. The Uses of Philosophy In Everyday Life, London 2001 [1996], p. 168. Original: A. Comte-Sponville, Petit traité des grandes vertus, Paris 1995, p. 223. 
Again, the way different prominent leaders make use of religious discourses did vary and still does. In June 2009, the President of the United States Barak Obama went to Cairo to support a truth transcend[ing] nations and peoples (...) [which] is a belief that pulsed in the cradle of civilization, and that still beats in the hearts of billions around the world. It's a faith in other people. ${ }^{62} \mathrm{He}$ claimed that There's one rule that lies at the heart of every religion - that we do unto others as we would have them do unto us. ${ }^{63}$ Here again, we see how a well-known old religious saying is used in a new context disregarding different previous contextual interpretations. President Obama uses it to promote a sustained effort to listen to each other; to learn from each other; to respect one another; and to seek common ground. ${ }^{64} \mathrm{He}$ stands up for 'human rights' as he endorses that all people yearn for certain things: the ability to speak your mind and have a say in how you are governed; confidence in the rule of law and the equal administration of justice; government that is transparent and doesn't steal from the people; the freedom to live as you choose. ${ }^{65}$ Obama invests in a faith in other people. ${ }^{66}$

62 B. Obama, On an New Beginning. Remarks by the President at Cairo University, June 4, 2009, \$69, at <https://obamawhitehouse.archives.gov/the-press-office/remarks-president-cairo-university-6-04-09>, 3 March 2021.

63 Ibid., $\$ 69$.

64 Ibid., $\$ 68$.

65 Ibid., $\$ 46$.

66 The speech that President Obama delivered at Cairo University on June 4, 2009 was 6000 words long. At the beginning, President Obama stresses the importance of seeking common grounds with an out of context reference to a specific religious saying. Let me mention the quote again, now with the reference to the Holy Koran at the end: There must be a sustained effort to listen to each other; to learn from each other; to respect one another; and to seek common ground. As the Holy Koran tells us, "Be conscious of God and speak always the truth.” (Applause.) Ibid., \$6.

President Obama came to Cairo to seek a new beginning between the United States and Muslims around the world, one based on mutual interest and mutual respect, and one based upon the truth that America and Islam are not exclusive and need not be in competition. Instead, they overlap, and share common principles - principles of justice and progress; tolerance and the dignity of all human beings. Ibid., $\$ 5$.

He declared that America holds within her the truth that regardless of race, religion, or station in life, all of us share common aspirations - to live in peace and security; to get an education and to work with dignity; to love our families, our communities, and our God. These things we share. This is the hope of all bumanity. Ibid., $\$ 14$.

The then President of the USA listed some of the great challenges of sharing the world in the 21 st century and said: That is the responsibility we have to one another as human beings. And this is a difficult responsibility to embrace. For human history has often been a record of nations and tribes - and, yes, religions - subjugating one another in pursuit of their own interests. Yet in this new age, such attitudes are self-defeating. Given our interdependence, any world order that elevates one nation or group of people over another will inevitably fail. So whatever we think of the past, we must not be prisoners to it. Our problems must be dealt with through partnership; our progress must be shared. Ibid. \$16.

Then, Obama addressed in details four sources of tension in our contemporary world. The fourth being democracy. He stressed that he has an unyielding belief that all people yearn for certain things: the ability to speak your mind and have a say in how you are governed; confidence in the rule of law and the equal administration of justice; government that is transparent and doesn't steal from the people; the freedom to live as you choose. [stressing that] These are not just American ideas; they are human rights. And that is why we will support them everywhere. Ibid., $\$ 46$. 
Also, in relation to the processes of change leading to new ways of relating to duties and rights, it is worth noticing that by formally addressing the 'Muslim world' with this speech, the President of the United States Barak Obama endorsed the idea that it had become necessary for the leader of the first world power to address a transnational community designated by its supposed religious affiliation. ${ }^{67}$ The fact that local powers and religions ended up confronting and influencing on a global scale has made the necessity of a dialogue more evident than it was at the time when Michel de Montaigne wrote: Nothing in all the world has greater variety than law and custom. What is abominable in one place is laudable somewhere else. (...) Any object can be seen in various lights and from various points of view: it is chiefly that which gives birth to variety of opinion: one nation sees one facet, and stops there; another sees another. ${ }^{68}$

The fact that democrat, communist, and religious leaders equally well refer to the necessity of a submission to an unquestionable 'truth' has also called the attention of critical minds who have today many more kinds of knowledge at their disposal than Montaigne did. It interests and involves historians, semioticians, social psychologists, political scientists, philosophers, economists and more. The degree of dogmatism, the structure of the argumentation, the relation between the concepts, abstractions call attention. For instance, Stalin and John Paul II both try to impose their specific compulsory behavior with reference to an absolute truth that no one has the right to question. That of the pope is referred to as coming from above, that of Stalin from within as a socio-historical necessity. Still, they have in common that both their truths are revealed and holy: they are indisputable and anyone questioning them is firmly punishable. According to John Paul II, he is damned. According to Stalin, he must be wrecked. With Obama, it is different: he refers to common human desires. The reference to the truth is that of tolerance and the dignity of all human beings. ${ }^{69}$ Everyone has the right to question the beliefs and opinions of others but not to impose their own.

Obama refers to the truth that regardless of race, religion, or station in life, all of us share common aspirations - to live in peace and security; to get an education and to work with dignity; to love our families, our communities, and our God. These things we share. This is the hope of all humanity. ${ }^{70}$ Clearly, Obama refers to human desires and human rights not as a necessity bestowed from above as the Pope does, or demanded from within a closed system as Stalin did. Obama does not refer to a common god either. Rather, he refers to 'everyone.' In Obama's statement, it is 'everyone' that is common.

To conclude, President Obama expressed his belief that There's one rule that lies at the heart of every religion - that we do unto others as we would have them do unto us. (Applause.) This truth transcends nations and peoples - a belief that isn't new; that isn't black or white or brown; that isn't Christian or Muslim or Jew. It's a belief that pulsed in the cradle of civilization, and that still beats in the hearts of billions around the world. It's a faith in other people, and it's what brought me here today. Ibid., $\$ 69$. D. Allès, La part des dieux - Religion et relations internationales, Paris 2021, p. 7. M. de Montaigne, The Complete Essays..., pp. 654-655. Original: M. de Montaigne, Les Essais Livre II..., pp. 399-400; or: M. de Montaigne, Les Essais..., p. 616.

B. Obama, On an New Beginning..., $\$ 5$. 
It is the human rights that we must have and share in common. We have the right to love our families, our communities, and our God even though those communities and gods differ. The term 'our' is quite mundane. It does not refer to a supreme 'He,' but to a communal 'we.' Obama refers to a hope among us.

Beside the fact that there is no longer a compulsory damnation or rejection attached to the social imaginary, ${ }^{71}$ there is no compulsory necessity - neither from within nor from above. Obama uses the concept of truth in another way. In this system of thought, truth is not above values; values decide of truth. It is an upkeeping process, not a submission process; it is an interactive process where everyone has the right to act instead of the obligation to submit. Hope is valued more than faith. Desire is not appeased/ satisfied by truth. ${ }^{72}$

Obviously, as Obama refers to the truth that regardless of race, religion, everyone has the right to live in peace and security; to get an education and to work with dignity, and to appreciate and treasure his/her family, community, and God. Everyone in this process participates in the general maintenance and further development of value systems they are related to. The truth here is that everyone relates to values interactively. And, [f]or those who, as André Comte-Sponville, recognize that values and truth belong to two different orders (the latter to that of knowledge, the former to that of desire), this disjunction provides an additional reason for being tolerant: even if we had access to absolute truth, everyone would not be obliged to respect the same values or live the same way. ${ }^{73}$ Things have changed. There's always been values and norms; still the ways they've been conceptualized in ethical and political systems evolved historically. Today, [t]he word value indicates that it is impossible to rely any longer on a guarantor recognized by all (nature, reason, God, History); it indicates a situation in which all figures

71 The term 'social imaginary' here refers to the fact that the institution of society is in each case the institution of a world of imaginary significations. It is "the unceasing and essentially undetermined (social-historical and psychical) creation of figures/forms/images on the basis of which alone there can ever be a question of something. What we call 'reality' and 'rationality' are its work", p. 3. Original: C Castoriadis, L'institution imaginaire de la société, Paris 1975, p. 7.

72 In his speech, President Obama only referred to monotheistic religions. One of the main reasons for that must be the fact that he came to Cairo at a time of great tension between the United States and Muslims around the world. B. Obama, On an New Beginning..., $\$ 2$, to contradict the tendency of many Muslims to view the West as hostile to the traditions of Islam. Ibid., $\$ 2$. However, as I just pointed out, Obama's argumentation is political and not religious. He could use the same speech just by replacing the term our God with 'our religious beliefs,' the main point being that even though there are different religious beliefs, we humans should figure out how to live in peace and respect each other regardless of race or religion.

In Redemptor Hominis, from March 4, 1979, Pope John Paul II also referred to the necessity to approach all cultures, all ideological concepts, all people of good will. [All Christians] approach them with the esteem, respect and discernment that since the time of the Apostles has marked the missionary attitude, the attitude of the missionary" (John Paul II, Redemptor Hominis, no. 12, at <https://www.vatican.

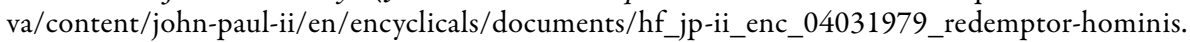
$\mathrm{html}>, 2$ March 2021). Still the missionary attitude the pope refers to differs radically from the political attitude of Obama.

73 A. Comte-Sponville, $A$ Short Treatise on the Great Virtues... , p. 169. Original: A. Comte-Sponville, Petit traité des grandes vertus..., p. 224. 
of transcendence have become blurred. ${ }^{74}$ We live in a world where everyone does not feel compelled/obliged to respect the same values or live the same way. Different representations and aspirations formerly linked to determinisms limiting the power of common debate historically gained new forms of attention and commitment from individuals and groups.

The way the terms of values and rights are intertwined in modern political debates reflects the introduction of another way to maintain a community between humans as different systems of indisputable truth from above ended up jeopardizing each other and themselves. Contrary to former political discourses, it is supposed to value everyone's right not to be totally controlled by one of the temporal political powers claiming to be entitled to impose their interpretation - and practical use - of an unquestionable eternal truth; an unquestionable truth which ended up being differently promoted, defended and managed by competing authorities and more obviously served private and collective interests. Power and interpretation disputes set the stage for social change. Historians and sociologists revealed the importance of critical and creative social engagement for any society and all social relations became more obvious in the process of competition and disintegration following the religious wars in Europe ${ }^{75}$ the rise and fall of the great powers, ${ }^{76}$ and the birth of the modern world. ${ }^{77}$

Making sense together is different from inheriting it ready-made. It implies another form of respect, that for the desires of others. It does not mean that those desires can be clearly identified or expressed, neither are they more 'true' than former representations of truth.

We must not reduce desire to wants and needs. Desire cannot be reached or met; it is ephemeral. It is always fluid but it has neither a source nor a delta. Desire has more in common with sound, which melodies are bound to make use of, than with seeds that must grow and need to be irrigated. It can never be fulfilled. It is insatiable. Desires are always related to other desires and thus always socially expressed. They rely much more on the condition of the social bond than on the evolution of supply and demand. Even when consumers do express a cultural project, it is not the expression of their will but the result of many interactions, most of which are unconscious. ${ }^{78}$

Individuals do not really choose the questions they have to respond to or the terms in which they will be posed, nor do they control the ultimate meaning of the response

74 C. Lefort, "The Idea of Humanity and the Project of Universal Peace", in idem (ed.), Writing. The Political Test, transl. by D.A. Curtis, Durham-London 2000, p. 144. Original: C. Lefort, "L'idée d'humanité et le projet de paix universelle", in idem (ed.), Ecrire à l'épreuve du politique, Paris 1992, p. 230.

75 P. Miquel, Les guerres de religion, Paris 1980.

76 P. Kennedy, The Rise and Fall of The Great Powers. Economic Change And Military Conflict from 1500 to 2000, New York 1989.

77 Ch.A. Bayly, The Birth of the Modern World 1780-1914. Global Connections and Comparisons, Oxford 2005.

78 D. Bouchet, "Desire”, in D. Southerton (ed.), Encyclopedia of Consumer Culture, Volume 1, Los Angeles-London 2011, p. 444. 
given together. As always, the consequences of our acts are launched into an ever unfolding social-historical world, and they escape us.

To refer to human desires and human rights does not provide an answer to the open question that religions tried to answer (Why humans on Earth?). It is just taking into consideration the fact that different concepts of what is to be asked and how to address those questions have arisen and spread.

Human rights should not be reduced to - or even confused with - the claim for everyone to have the right to decide or to participate in political decisions. Most crucial is the principle of legitimacy they build upon.

Just like before when humans in charge of political decision were supposed to apply principles originating from outside and above the community of people, those supposed to act do not necessarily do as they are supposed to. Thus, it is not efficiency and consistency as such that should call our attention, but what they refer to: the principle of legitimacy which ultimately - or rather fundamentally - orients human demands and claims. Human rights are fundamentally a principle of legitimacy. They are the principle of legitimacy that replaced the religious one. To which source can we relate our norms and values, our social bond, our community laws, our power system? How does all this make sense and where does this sense-making come from? Well, before it was historically challenged and turned upside down, the source was external and superior to the domain it governs. The source of legitimacy being transcendent, societies were bound to be traditional. Communities had to refer to their founding past and maintain the order given from above. Everyone had a predetermined place and role in this pre-existing system. Human rights could not make sense, nor made a difference in such a world of conservative subjection. But if the source of legitimacy is set within the human community, the focus is clearly more on the dynamics of social interactions through individual participation. What is right is no longer given once for all, and the role of everyone is not to maintain society as it was, but to participate in its further development. Everyone has the right to actively support - or not - one direction or another, even a restoration. A modern community can act traditionally. A modern society can end up looking traditional. Still, once the principle of legitimacy no longer originates from beyond mankind, such communities and societies are a product of the exercise of human rights. Some groups of humans can deny others their right to participate, it will not obliterate anyone's role, neither one's own nor the others'.

Whether everyone admits it or not, human rights are at the very basis of any society as soon as it is no longer possible to maintain the monopoly of a transcendental source of the social. When it became possible to renounce the truth from above, disown the social models of the past, and defy all-encompassing leading social authorities, an unmendable breach opened.

In order to understand why this breach really is unmendable, even though a wide range of religions and states still struggle today to maintain or expand their grip and fight to keep control, we have to look into social history. We must study how first the emergence of the states and later their endless competition on an ever-growing world 
market irremediably affected the triangular relationship between human beings, the sacred, and political powers.

We should take notice that for such a renunciation of the universal truth to be possible, there had to be a direct and internal relation between a human being and the supreme power. Such a relation was not conceivable in so called 'primitive societies' where contact with the foundational principle took place through a hierarchical subordination of every part to the whole, and supreme powers were transmitted through the bonds between beings. Think of the Indian communities that, among others, Bartolomé Las Casas met and that were studied later by anthropologists. The 'social imaginary' of the conquerors of Latin America made it at the time almost impossible for them to perceive and understand the humane uses of power among the Indians of the Americas.

Five centuries later, the anthropologist Pierre Clastres (1934-1977), who did his fieldwork among the Guayaki in Paraguay, pointed out in his Society Against The State that the leader was more a servant than a chief and that the reason for this was that Indians had a radically different view of their place and role in their environment. In these so-called 'primitive societies' the source of meaning and law on Earth was considered as being completely beyond the grasp of human actors. And it did not have to be so because they did not know better. Rather, they had established a certain relation to their environment and had not yet met others who ended up making a different choice. Reading Pierre Clastres helps us realize that even the concept of power is not as univocal as often thought: To a mind shaped by cultures in which political power is endowed with real might, the distinctive rule of the American chieftainship is asserted in paradoxical fashion. Just what is this power that is deprived of its own exercise? What is it that defines the chief, since he lacks authority? And one might soon be tempted, yielding to the temptation of a more or less conscious evolutionism, to conclude that political power in these societies is epiphenomenal, that their archaism prevents them from creating a genuine political form. However, to solve the problem in this fashion compels one to frame it again in a different way: from where does this institution without 'substance' derive its strength to endure? For what needs to be understood is the bizarre persistence of a 'power' that is practically powerless, of a chieftainship without authority, of a function operating in a void. ${ }^{79}$

In his outstanding Political History of Religion, Marcel Gauchet expanded on this and explained how the formulations of a divine image, rather than the reinforcement of human dependence, initiated a process of re-appropriation of meaning and law. In the first chapter entitled Primeval Religion or the Reign of the Absolute Past, referring to and commenting the works of Pierre Clastres, Claude Lévi-Strauss, and Louis Dumont, Gauchet points out that if the customary modes of human coexistence are accepted as wholly predefined, then no conflict arises between social actors about the content and

79 P. Clastres, Society Against the State, transl. by R. Hurley in collaboration with A. Stein, Oxford 1977 [1974], p. 21. Original: P. Clastres, La société contre l'Etat. Recherches d'anthropologie politique, Paris 1974, p. 16. 
forms of collective relations. All possible conflict between individuals and groups is given precise predetermined limits as to its prospects and possible outcomes. ${ }^{80}$

Whereas, when the existence of a unique principle secretly controlling all of life and moreover supposed to care for and/or be interested in human behavior was once postulated, the status of every single human being was radically transformed: Even though everyone remains caught in the local network of community constraints under the domination of an earthly power, the relation to the supreme power no longer necessarily has to be transmitted through the social bond.

Thus, when humans started postulating the existence of a unique principle secretly controlling all of life, an internal separation corresponding to the fracture in being arose. This hiatus between appearances and reality resulted in the emergence of an ethics of withdrawal and mobilization giving us access, within the self, to the true good concealed by human intercourse. ${ }^{81}$ And Gauchet stresses that the Christian imperative to convert, instigated by the revelation of the creator's interest in his creatures, was simply an extreme version of this. ${ }^{82}$

This new relation between inner and a social being marked a turning point. From now on, an inner being existed alongside, or rather beneath, the social being, an inner being (...) now ultimately absolutely self-relying in its relation to God. In every believer there coexists one actor fettered by the world and another unfettered through commitment to the other world. ${ }^{33}$ If it had not occurred, neither social individualism nor universal human rights could have been discussed today.

\section{THE RESPONSIBILITY OF THE STATE}

In his Political History of Religion, Marcel Gauchet points out three crucial transformations of the interaction between the invisible and the visible; three reformulations of humans' indebtedness toward what goes beyond them. Each one was a decisive step toward recovering themselves. The first of these major upheavals corresponds to the emergence of the state ca. 5000 years ago. The second was brought about by the advent of a divinity from above and of a religious rejection of this world. The third upheaval is represented by Western Christianity's internal trajectory.

What looked like a continual deepening of the experience and conception of the Other,

80 M. Gauchet, The Disenchantment of the World. A Political History of Religion, transl. by O. Burge, Princeton 1997 [1985], p. 27. Original: M. Gauchet, Le désenchantement du monde. Une histoire politique de la religion, Paris 1985, p. 18.

81 Ibid., p. $64 \&$ p. 76.

82 Ibid.

83 M. Gauchet, Le désenchantement du monde..., pp. 76-77. The original version being un homme intérieur, absolument indépendant en ultime ressort, au fond de lui-même, dans sa relation à Dieu, I translated it as : an inner being now ultimately absolutely self-relying in its relation to God. In the English translation it reads: an inner being ultimately completely independent of God [SIC], which is not a correct translation. 
proves to have been a progressive re-appropriation of what was initially removed. The gods withdraw and simultaneously the unquestionable becomes questionable, being affirmed by the hold humans have on the organization of their own world. Emphasizing divine difference proves to go hand-in-hand with broadening the power humans have over themselves and the order they comply with. ${ }^{84}$ There could not have been any concept of human rights - nor of course any debate about human rights - if human beings had not been through such a process of re-appropriation of their responsibilities. It took time and did not happen in one step but three, and the implementation of a discourse - and international institutions - dealing with human rights can be considered as the successive fourth step.

The most important of these upheavals is undoubtedly the first one: the birth of the state was a radical change for human societies because it modified in every way their relation to change and hence their rate of change. The advent of political domination acts contrariwise the so-called primitive societies which were organized to remain unchanged and to deny collective division. Not only does political domination generate much greater instability and more effective transformations, it also reshapes both the external and internal social relations in such a way that the interplay of their most substantial forces now tends to loosen the previously unchallengeable human bonds. The social bond and its link to the outside world are more or less consciously redefined. The birth of the state sets up a debate about the meaning and legitimacy of the whole at the heart of the collective process as the order of things passes from the level of the received to that of the willed.

Whereas before the religious severance separated humans from their origins, now the severance occurs within society between humans speaking and organizing in the name of the gods and the others. This political severance introduces a dynamic, a principle of change, into the heart of collective practices on the physical, spiritual, and symbolic levels. ${ }^{85}$ It brings power into the midst of human affairs. ${ }^{86}$ The crucial point is that divine otherness, whatever its shape, has been transported into the social space and the nonbuman has been incorporated into the structure of human ties. ${ }^{87}$

Thus, the instituting force became visible and accessible and the gods increasingly dependent on what is supposed to depend on them, that is, on the actions of an everchanging system they are supposed to keep intact. ${ }^{88}$ The responsibility of the state was to maintain cohesion and ensure working order in accordance with a code handed down from above. But this code had to be interpreted and managed in context. Consequently, the sovereign's leadership, actions, and command were bound to be coercive and to

\footnotetext{
$84 \quad$ Ibid., p. $34 \&$ p. 27.

85 Ibid., p. $36 \&$ p. 30.

86 There are many versions of this phenomenon, from the god as living despot where the Other that humans depend on openly adopts a human form, through to the temple where the god is actually present without being properly incarnated in human form, but with servants and human mediators. Ibid., p. 35 \& pp. 9-30.

87 Ibid., p. $36 \&$ p. 30.

88

Ibid.
} 
exceed his sacred role. Thus, a subjective dynamic emerged thoroughly challenging and changing what was instituted as being unchangeable. Internal and external confrontation were bound to occur.

Once begun, there can be no turning back. It is as if the human action had initiated an unstoppable trend, putting them permanently at odds with what their beliefs continue to assert as out of reach, while their new existential framework forced them to question the social bond determined from outside. ${ }^{89}$ The emergence of an independent or rather autonomous relation to the transcendental made it possible to question the legitimacy of a position. The power of a few individuals to act in the name of the gods is the barely perceptible, yet irreversible step toward everyone having an influence on the gods' decrees - the imperceptible yet definite beginning of a collective grasp on the previously sacrosanct. ${ }^{90} \mathrm{To}$ express its authority over its subjects and the validity of its position the ruling power will soon end up expanding its sphere of influence.

Thus, the advent of the state altered the form and meaning of wars and this will have a tremendous impact on individual and collective identities and social interactions initiating a process: Because of the way each primitive social unit maintains its identity, war between them follows a pattern of differentiation or proliferation. The ceaseless interplay between alliance and discord, the permanent state of hostilities in one form or another, sustains and extends the multiplicity and dispersion of groups that are regularly threatened by internal splits. Each community maintains its identity by remaining in a potential state of conflict with all the others, and the dynamics of war always serve to widen the gaps. Should the opportunity arise, one group may expel or eliminate another, but it never absorbs the other group. However, once the State becomes a separate entity, part of its function is to expand and assimilate. The prospect of conquest is inscribed in the chain of subordination and is an active integral part of the political division. In practice, the power relationship precludes a state of equilibrium. Those above the common run of mortals are obliged to assert that they are increasingly higher, different, and removed from the others. Power continually strives to increase itself. This internal distance between the ruling authority and its subjects is what makes the unlimited absorption of the external world both conceivable and feasible. In the eyes of the system of domination, those dominated are all the same. In comparison to the overwhelming splendor of the despot, the appendages pale into insignificance. Likewise, there are and must be a limitless number of dependent and obedient subjects. In the same way, every other sovereign formation can only be grasped as something to be reduced: every subordinating power must itself be subordinated. ${ }^{91}$

This will bring about a new representation of human's position in the world and of each local state-held community's representation. The order of each particular community preserves its stability by being designated as a received order, yet the support for the system's absolute validity is shaken to its foundations by the sudden appearance of imperial universalism. For this reason wars of expansion could no doubt be justifiably considered

89 Ibid., p. $35 \&$ p. 29.

$90 \quad$ Ibid., p. 37 \& p. 31.

$91 \quad$ Ibid., p. 41 \& p. 38. 
one of the greatest spiritual and intellectual forces to have ever operated in history. ${ }^{92}$ Thus, with the emergence of the state came the imperial ambition to dominate the world. But clashes and discrepancies of interests and ideas between and within states will also open up for disagreement and doubt.

Not only goods but also ideas will be exchanged on global trade routes; the latter in a much less manageable way than before. The confrontation with the variety of religions and states will increase the dynamic tensions also within the existing communities. The neutralization of destabilizing factors will entail new forms and new distributions of involvement. State powers' control of their population will end up requiring more active participation by people in a sense-making debate.

The relations between states, markets and sense-making did evolve significatively during the last centuries. Markets ended playing a much more important role in sensemaking and individuals' consumption. The image of the market seems to me to be appropriate since markets essentially are competitive. Also, neither states nor religions ended up controlling values and norms. Opinions and behaviors are today much more influenced by marketing and stock-markets than by states and popes. Advertising and standardizing globally pervade all three angles of the formerly mentioned triangular relationship between human beings, the sacred, and political powers. The first modern globalization was the result of an imperialist domination imposing the values and norms of the West arrogantly upon the rest of the world. Then capitalism overtook the globalization process imposing its accumulation logic on all local cultures. Competitive production and consumption seem to be the new triangle. Today most religions and states have to refer to it almost as if it were an almighty god from above.

\section{THE PREVENTION OF VIOLENCE}

The human rights can thus be seen in relation to the institutional attempt to bring under control an all-encompassing market ending as a reducing agent deeply transforming the link between members of every society and taking over the role of all other institutionalized controlling powers as we entered the age of individualism where both dependency on the whole and indebtedness to the other are simultaneously relinquished. ${ }^{3}$

The issue of human rights arose in continuation with the uprising against competitive truth powers and continued developing in relation with the dealing of international conflicts. Today on an international level, [w]e should conceive human rights primarily as claims on coercive social institutions and secondarily as claims against those who uphold such institutions. ${ }^{94}$ Thus, referring to universal human rights can be seen as the total reversal of the former way of orienting the core argumentation of the reason and limit of common human action: Its origin and circumscription is not outside of mankind, but inside every man.

\footnotetext{
92 Ibid., p. $36 \&$ p. 31.

93 Ibid., p. $27 \&$ p. 18.

94 T. Pogge, World Poverty and Human Rights, Cambridge-Malden 2008, p. 50.
} 
The idea of human rights is not to force states to allow every single human to do anything (s)he wants, but to prevent powers claiming to be legitimate from imposing anything that suits them by ignoring the foundation and limits of their mandate. It can be seen as the fourth step.

Within the 'reversal' from transcendent truth to immanent values, the human rights argumentation developed progressively and differently in relation to the democratic discourse. Diverging conceptions of how to establish democratic institutions within and between nations arose.

No longer referring to a truth coming from an outside or inside logic, societies rely more consciously on values promoted actively by humans.

Again, we should not forget that Stalin referred to a historical truth within society functioning like the religious truth from above that motivated the religious wars. A serious analysis of the different political regimes is of course always required. Just as the different religious movements had different ways to respect their fellow humans in practice (Bartolomé Las Casas for instance did not subsume everything to the subjection to God), the different communist movements also did. Thus Cornelius Castoriadis could write in 1993: Whereas - for Marx, for example - the collective combat for the transformation of society seemed to include and to subsume all else (...), the monstrosity of actual communist regimes has led many people, and among them some of the best, to impugn every overall aim or goal for society (a position that is, in the final analysis, simply incoherent) and to seek in their individual consciences (or in transcendent principles) the norms that could animate and guide them in their resistance to these regimes. ${ }^{95}$

Violence is the main thing we are dealing with that dictators and terrorists do, i.e. lack of respect for others and reducing them to the status of mere things. We are not dealing with religion which originally sought to bring people together and help to counteract confusion and dismay. Dictators are disrespectful of their fellow beings and impervious to reason and knowledge. 'Soldiers of God' are fanatical terrorists who take all other humans to be merely things they can use for their own ends. In actual fact, however, they have transformed themselves into things. ${ }^{96}$

To accept the discussion of human values is a proposal to put forward the importance of disagreement and diversity for the common good. To promote the universality of human rights is more than protecting individuals; it is working against the tendency of established power to ignore the diversity of those they represent and serve, as well as to help them to know better other powers they must deal with internationally.

As already mentioned, human rights are at the very basis of any society as soon as it is no longer possible to maintain the monopoly of a transcendental source of the social.

95 C. Castoriadis, World In Fragments. Writings On Politics, Society, Psychoanalysis, and The Imagination, ed. and transl. by D.A. Curtis, Stanford 1997, p. 109. Original: C. Castoriadis, "Le cache-misère de l'éthique", in C. Castoriadis, La montée de l'insignifiance. Les carrefours du labyrinthe IV, Paris 1996, p. 207.

96 D. Bouchet, "Democratic Conscience versus the Madness of Fanatical Terrorism", Knowledge Cultures, vol. 3, no. 1 (2015), pp. 11-19. 
All former religious legitimizations are constantly questioned and all endeavors to close the gaps or mend the breach remain paper over the cracks.

Human rights are a principle of legitimacy, not a detailed and definitive reductionist definition. They inevitably leap into the cracks but the way they will make sense and take shape in different cultures will vary. Political institutions within and across the different cultures are actively contributing to the new political debate focusing on each single human being in his/her own specific cultural context. The universality of the reference will not prevent a diversity of understandings. Just as there were several cultural interpretations of rights and duties with reference to the transcendent, there will be different cultural proposals from an immanent perspective. Unlike the competition on the ever-growing world market, the political debate about the human rights does not have to result in an unconsidered reductionist homogenization process. Cultural differences can and will contribute to the debate. As a universal and immanent principle of legitimacy, human rights entail every perspective to be taken into account as long as it does not neglect any human beings own right.

In 1951 in the 'Concluding Remarks' of The Burden of Our Time which was later to be published under the title of The Origins of Totalitarianism, Hannah Arendt told us that The concept of human rights can again be meaningful only if they are redefined as a right to the human condition itself, which depends upon belonging to some human community, the right never to be dependent on some inborn human dignity which de facto, aside from its guarantee by fellow-men, not only does not exist but is the last and most arrogant myth we have invented in all our long history. The Rights of Man can be implemented only if they become the prepolitical foundation of a new polity, the prelegal basis of a new legal structure, the, so to speak, prehistorical fundament from which the history of mankind will derive its essential meaning in much the same way Western civilization did from its own fundamental origin myths. ${ }^{97}$

The 'one human right,' in [Hannah Arendt's] framework, must become the conceptual foundation of a positive, human-constructed cosmopolitan law that guarantees the buman condition for every person, that is, the right of citizenship in a political community. This right alone can be guaranteed by 'the political existence of mankind,' because it is the basis for the continued existence of human life, the 'foundation for human community as such. ${ }^{98}$

As already mentioned in part 4, Bartolomé de Las Casas, who had been a willing participant in the conquest of the Americas from 1502, ended up feeling the necessity to defend the rights of the indigenous peoples. Back in Spain he acted politically to defend the rights of the Indians. In his Very Brief Account of the Destruction of the Indies, Las Casas branded the conquest of Mexico as the climax of injustice and violence and tyranny committed against the Indians. He denounced Indian slavery as torments even

7 H. Arendt, "Concluding Remarks", in eadem (ed.), The Origins of Totalitarianism, with an Introduction by S. Power, New York 2004 [1951], p. 631.

98 L. Sutherland, “The Divergent Cosmopolitanisms of Hannah Arendt”, in A. Kumar Giri (ed.), Beyond Cosmopolitanism. Towards Planetary Transformations, Singapore 2018, p. 155. 
harder to endure and longer lasting than the torments of those who are put to the sword. He accused people and institutions of the sin of oppressing the Indian. He pointed out that the reason why the Christians have killed and destroyed so infinite a number of souls is that they have been motivated by their wish for gold and their desire to enrich themselves in a very short time..$^{99} \mathrm{He}$ declared that those crimes he had witnessed were condemned not only by the law of God, but by all human laws. ${ }^{100}$

When he presented Emperor Carlos V a brief summary of his Very Brief Account... in 1542, the Emperor, horrified, immediately promulgated forty new laws proclaiming the freedom of Indians - freedom of work, of residence, and to dispose of their own property - and making provision for strict sentences for recalcitrant settlers. However, the pressure was so strong that those laws were repealed four years later, in 1546.

In his hugely readable riveting account of how Europe's discovery of the Americas triggered a global upheaval, Charles C. Mann tells us significant details which can help in reflection upon different systems of legitimacy: As the king surely knew, the Spanish monarchy had been struggling to define its Indian policy since before he was born. His grandparents, King Fernando and Queen Isabel [1451-1504], had been stunned when Colon informed them that they now ruled over multitudes of people whose very existence had been previously unsuspected. The monarchs, devout Christians, worried that the conquest could not be justified in the eyes of God. Colon's new lands had the potential of enriching Spain, an outcome they of course viewed as highly desirable. But obtaining the wealth of the Americas would involve subjugating people who had committed no offense against Spain.

As Fernando and Isabel saw it, Indian lands were not like the Islamic empires whom they and their royal ancestors had fought for centuries. Muslim troops, in their view, could be legitimately enslaved-they had conquered most of Spain, exploited Spanish people, and, by embracing Islam, rejected Christianity. (For similar reasons, the Islamic empires freely enslaved Spanish prisoners of war.) Most Indians, by contrast, had done no wrong to Spaniards. Because American natives had never heard of Christianity, they could not have turned away from it. In 1493, Pope Alexander VI resolved this dilemma of conscience. He awarded the sovereigns 'full, free and complete power, authority, and jurisdiction' over the [Indians] if they sent 'prudent and God-fearing men, learned, skilled, and proven, to

99 B. de Las Casas, Très brève relation de la destruction des Indes. In Las Casas's 'sure, truthful estimate,' his countrymen in the first five decades after Columbus wiped out 'more than twelve million souls, men and women and children; and in truth I believe, without trying to deceive myself, that it was more than fifteen million.' Twenty years later, he raised his estimate of Indian deaths - and hence of the initial populationto forty million. Ch.C. Mann, 1491. The Americas before Columbus, p. 133.

100 B. de Las Casas, Très brève relation de la destruction des Indes, p. 79. Spanish original: Más han muerto los españoles dentro de los doce años dichos en las dichas cuatrocientas y cincuenta leguas, a cuchillos y a lanzadas y quemándolos vivos, mujeres y niños y mozos y viejos, de cuatro cuentos de ánimas, mientras que duraron (como dicho es) lo que ellos llaman conquistas, siendo invasiones violentas de crueles tiranos, condenadas no sólo por la ley de Dios, pero por todas las leyes humanas, como lo son, y muy peores que las que hace el turco para destruir la Iglesia cristiana. Y esto sin los que han muerto y matan cada dia en la susodicha tiránica servidumbre, vejaciones y opresiones cotidianas; B. de Las Casas, Brevísima relación de la destrucción de las Indias, San Juan 2019 [1552], p. 32. My emphasis. 
instruct [them] in the Catholic faith.' Thus, Conquest was acceptable if done for the purpose of bringing the conquered to salvation.

Nothing could be more legitimate than conversion. "Under the law, Indian Christians were entitled after baptism to be treated exactly like Spanish Christians, who could not be enslaved. But colonists argued the contrary; Indians were, in effect, less human than Europeans, and thus could be forced to work even after they converted." 101

Finding out the motivation of those converting and those converted has always been a challenge. Let me introduce a pertinent example concerning another intercontinental relation and an otherwise respected man soon to become a great contributor to cross-cultural understandings. In 1518 a Spanish Christian pirate presented Pope Leo $\mathrm{X}$ with a captured North African traveler and diplomat from Fez named al-Hasan alWazzan. Better known today as Leo Africanus thanks to a wonderful novel by Amin Maalouf, ${ }^{102}$ he was first imprisoned, then baptized by the pope at an ornate ceremony at St. Peters on January 6, 1520. In a masterpiece of historian craft, Natalie Zemon Davis points out that Al-Wazzan's eventual decision to say that he believed the articles of the Christian faith was in part coerced: continued imprisonment and/or enslavement would have been his destiny otherwise. ${ }^{103} \mathrm{He}$ surely pondered the fate that might await him if he showed no sign of cooperation: languishing in prison, or perhaps enslavement like any common Muslim captive, working as a domestic if he were lucky, or in stables or farming or in the galleys. What answers he gave remain unknown. Might he have suggested that Sultan Mubammadibn al-Hasan of Tunis was seeking association with Christian Venice since they both currently feared the expanding power of the Muslim Khayr al-Din? Might he have wondered whether the Venetians had asked the Tunisian ambassador about himself, since his imprisonment at the Castel Sant'Angelo had been reported months before to them?

101 Charles C. Mann tells us further that the New Laws had big loopholes: Indians still could be enslaved if they were captured while resisting Spanish authority. Because one could always claim that a given person or group was resisting authority, the loophole amounted to a license to enslave. Nonetheless, the New Laws so angered the conquistadors that they decapitated the new viceroy of Peru when he tried to enforce them. The viceroy of New Spain (the empire's holdings north of Panama) prudently suspended the laws before they came into effect. Nonetheless, the trend was clear: it was going to be harder for people like Cortés to force Indians to work for them. Ch.C. Mann, 1493. How Europe's Discovery of the Americas Revolutionized Trade, Ecology and Life on Earth, New York 2011, p. 386. A few pages before, Mann points out that the conquerors had little interest in evangelization: Although often personally pious, they were more concerned with Indian labor than Indian souls. Colon was an example. Despite being fervently, passionately devout, he had appalled Isabel in 1495 by sending 550 captured Taino to Spain to sell as galley slaves. (Galleys were still common on the Mediterranean.) Colon argued that enslaving prisoners of war was justified - he was treating the Indians who had attacked La Isabela as Spaniards had long treated their military enemies. In addition, he said, the Indians' fate would deter further rebellions. Isabel didn't agree. Slowly growing angry, she watched shackled Taino trickle into the slave markets of Seville. In an outburst of fury in 1499 she ordered all Spaniards who had acquired Indians to send them back to the Americas. Death was the penalty for noncompliance. Ibid., p. 384.

102 A. Maalouf, Leo the African, transl. by P. Sluglett, London 1994 [1986]. Original: A. Maalouf, Léon l'Africain, Samarcande \& Les jardins de lumière, Paris 1992.

103 N.Z. Davis, Trickster Travels: A Sixteenth-Century Muslim Between Worlds. The Search for Leo Africanus, Paris 2006, p. 67. 
If such questions were put, might he have hoped that word of his situation would get back to his sultan and his family in Fez? ${ }^{104}$ Those last comments refer to diplomacy at work.

Another Dominican of the $16^{\text {th }}$ century made an equally important contribution to that of Bartolomé Las Casas: Francisco de Vitoria ( 1492-1546) who never saw the 'New World,' built on earlier Dominican thought to consider what was happening in America in light of 'just war' theory. For the last two decades of his life, Vitoria was highly influential as the leading theologian in Salamanca University. He introduced the practice of studying the Summa Theologica of Saint Thomas Aquinas ( 1224-1274), replacing the commentary on the Sentences of Peter Lombard ( 1100-1160). JeanRobert Armogathe, research director at the École Pratique des Hautes Études, Religious Studies section (Sorbonne), tells us that Vitoria is renowned for his clarity and his talent for exposition and he does not neglect the political context in which he lives: he supports the efforts of Las Casas for a colonial policy inspired by Christian principles, particularly for the defense of the Indians. Vitoria is the first modern theorist of 'buman rights,' which he considers to be stemming from natural law; denying the pope any right in the temporal domain of the princes, he refers jurisdiction to the 'buman republic,' which guarantees respect for the law; its influence largely affected legal theories of the seventeenth century. ${ }^{105}$

In his history of Christianity, MacCulloch, Professor of the History of the Church at Oxford University, stresses that there seemed to Vitoria little that was just in the idea of a crusade, particularly in its exploitation in America, even though - as earlier mentioned - conventional Christian legal wisdom saw nothing wrong in enslaving non-Christians captured in a just war. According to Vitoria, [w]ar was only justified as a response to inflicted wrong, and the various peoples of America had offered no wrong to Spaniards before the Spaniards decided to move in on their territory. The Aztec practice of human sacrifice did offer a different justification for Spanish action in Central America, since it was a clear offence against universal natural law. There were other possible interpretations of wrong: resistance to preaching the Gospel, for instance, once the intention to do so had been proclaimed in the Requirement. ${ }^{106}$

Most interesting, Vitoria also considered authority within commonwealths. He discussed it in terms of sovereignty, a ruler's untrammelled power within the boundaries of a commonwealth or state. Such sovereign commonwealths need not be Christian: Aztecs or Ottomans were as sovereign as Fernando and Isabel. If so, Pope Alexander had no right to grant sovereignty in America to Spaniards in 1493, at the same time as he perfectly legitimately granted them exclusive rights to preach the Gospel. Such reasoning (coming from an Iberian Catholic tradition which had already put the pope firmly in his place) was a clear denial of that idea of universal papal monarchy which had originally fueled Western Christendom's unity in the twelfth century. ${ }^{107}$

104 Ibid., p. 65.

105 J.-R. Armogathe, "Vitoria, Francisco de (1492 env.-1546)", in Encyclopedia Universalis, Paris 2021, at <https://www.universalis.fr/encyclopedie/francisco-de-vitoria/>, 7 March 2021, my translation.

106 D. MacCulloch, A History of Christianity..., p. 693.

107 Ibid. 
And even more relevant for us here, Francisco de Vitoria's discussions had a wider application. He was pioneering the concept of a system of international law, based on the older idea of ius gentium ('the law of peoples/nations'), the legal principles applicable to humans everywhere. His assertions heralded the end of belief in the crusade as a means of extending Western Christendom just when Europe began a wider mission to spread its particular brand of Christianity throughout the world. The question would soon arise as to whether Western Christianity was completely identical with authentic Christianity, but there was more to the development of international law than this. Western European political thought was to develop a relativistic concept of dealing with other cultures and other political units - eventually without reference to their religious beliefs or any sense that one religion was superior to another. Vitoria would have profoundly disapproved of this development, but it emerged as a consequence of Iberian worldwide adventures. ${ }^{108}$ Still, what is most interesting to us here is the emergence of a relativistic concept of dealing with other cultures and other political units.

Las Casas was convinced that the truth is in the gospel. He did not intend to suggest that all cultures were or are equal. Still, he thought that one does not have to give up one's own certainty to tolerate others, and that one can believe in the superiority of one's own credentials and nevertheless respect other cultures. Las Casas still wanted to preach. According to his catholic faith, the absolute truth had to be propagated, if not it would be like selfishly keeping a treasure only for oneself. Las Casas refers to Saint Augustine: to believe is to consent, and in order to consent one must absolutely be free. Thus, the Dominican Las Casas tried to figure out how to convert all other human beings in a respectful way. His book Del único modo de atraer a todos los pueblos a la verdadera religión (1537) - The only way to evangelize the whole world - was written between 1523 and $1527 .{ }^{109}$

Las Casas' principle of legitimacy was from above. Still his politic of conversion was from the side, so to speak. It was not based on coercion from above but on persuasion and mutual respect. He was a strong supporter of his faith. He also was a philosopher who understood that human beings always interpret what they are told or are imposed upon in context. In other words, when it comes to the adherence to a principle of legitimacy, coercion does not work. It has to make sense. Las Casas knew that human laws could prevent crimes, but that it was not the laws as such that would trigger faith.

Likewise, human rights seek adhesion in different cultural contexts. As in the times of Bartolomé Las Casas, different cultures are confronted and challenged by a principle of legitimacy that they cannot but perceive from their own points of view, from their own specific backgrounds.

Promoting the legitimacy of human rights requires an even greater understanding of the importance and signification of commitment in different cultural contexts because as already mentioned - contrary to former political discourses, that of human rights promotes everyone's right not to be totally controlled by any temporal political power. This

\footnotetext{
108 Ibid.

109 In Latin Las Casas book is entitled De unico vocationis modo.
} 
implies an even clearer respectful and critical adherence. Forcing a belief is less meaningful than ever. But this also implies an efficient universal prevention against local powers that do not tolerate free discussion of human values and locally oppress human beings kept coercively under their control. What Bartolomé Las Casas referred to as the sin of oppressing the Indian five hundred years ago still requires laws and institutions that can ensure they are respected and make clear why they must be followed. That kind of institutions and laws are today easier to promote, but persuasion is still needed. Relying almost solely on assertion from above, i.e., from international institutions, would be not only unethical and arrogant but also counterproductive. Reminding former colonization processes will bring much support to local powers, which could turn the discourse of universal human rights into foreign imperialistic propaganda and make any use of it innocuous. Respectful dialogue and persuasion are thus even more obviously required than in the time of Las Casas.

We have to remember that a radically new dimension of history has emerged in the $20^{\text {th }}$ century: the emergence of planetary humanity - or the emergence of worldwide scale humanity. All the disorders and crises of our present time include and prolong all former historical disorders and crises, but the present state of disorder cannot be reduced to those because of its utterly global characteristics. ${ }^{10}$ This radical globalization of the world and the new balance of powers makes cross cultural dialogue more required than ever. A respectful cross-cultural dialogue must build on universal transdisciplinary knowledge and refer to essential values. Human rights is a core issue as it calls for knowledge, dialogue and understanding based on a deep respect of all human beings.

According to Albert Camus (1913-1960), human beings live and can only live on the idea that they have something in common where they can always find each other again. (...) The world needs true dialogue, [and] the opposite of dialogue is both falsehood and silence. ${ }^{111}$ In 1948 Albert Camus made the following statement at the Dominican Monastery of Latour-Maubourg: Not feeling that I possess any absolute truth or any message, I shall never start from the assumption that Christian truth is illusory, (...) but merely from the fact that I could not accept it. ${ }^{112}$ Universal human rights remain a human dream and require that humans, globally confronting one another in so many ways now, have to strive for their interpretation of human rights together and respectfully.

Maybe we need some sort of 'faith', a word that Camus uses repeatedly. Anyway, there must be some faith in the strength of ideas to establish fair laws. When we represent the human being as a unique and indivisible individual, both equal to and irreducibly different from all others, we are performing an act of faith which clearly falls outside the realm of experimental science. ${ }^{113}$ Adding to this, the law cannot accomplish it alone.

110 E. Morin, Pour sortir du vingtième siècle, Paris 1981, pp. 342-343 or E. Morin, La complexité humaine, Paris 1994, p. 217, my translation.

111 A. Camus, Actuelles I. Ecrits politiques, Paris 1997, p. 171, my translation.

112 Idem, Resistance, Rebellion, and Death, transl. and introduction by J. O'Brien, New York 1961, pp. 6970. Original: A. Camus, Essais, Paris 1965, p. 371. Or: idem, Actuelles I. Ecrits politiques, p. 172.

113 A. Supiot, Homo Juridicus. On the Anthropological Function of the Law, transl. by S. Brown, LondonNew York 2007 [2005], p. 27. Original: A. Supiot, Homo juridicus. Essai sur la fonction anthropologique du Droit, Paris 2005, p. 45. 
We can think of the open letter written by the French journalist Antoine Leiris [born in 1981] to the murderers of his wife at the Bataclan in Paris on November 13, 2015 (90 killed and 416 injured, almost 100 critically): You will not have my hate:

Friday night, you took an exceptional life - the love of my life, the mother of my sonbut you will not have my hate. I don't know who you are and I don't want to know, you are dead souls. If this God, for whom you kill blindly, made us in his image, every bullet in the body of my wife would have been one more wound in His heart. ${ }^{114}$

\section{HUMAN RIGHTS: HUMANITY'S COMMON RESOURCE}

$\mathrm{UDHR}^{115}$ Article 4: No one shall be held in slavery or servitude; slavery and the slave trade shall be prohibited in all their forms.

UDHR Article 5: No one shall be subjected to torture or to cruel, inhuman or degrading treatment or punishment.

UDHR Article 9: No one shall be subjected to arbitrary arrest, detention or exile.

Terrorism and enslavement are appallingly common throughout the world. Today's fanatical terrorism and yesterday's enslavement of millions of Africans should not overshadow the incredible violence of the Iraq war in 2003 and the radical deterioration of life conditions of populations excluded from the world market.

We should analyze the political speeches of the American President George W. Bush in the same way as we looked into those of Las Casas and Sepúlveda. Likewise, we should investigate the argumentation of the World Bank and the International Monetary Fund. George W. Bush thought it right to use torture and terror against terror. The World Bank has a strong faith in market forces.

We should compare the three different historical declarations of human rights ${ }^{116}$ as we compared the declarations of three world leaders above. The Declaration of 1789 defined 'Man' as a purely rational being whose physical existence was taken into account only in provisions on sentencing. But history has since shown that civil and politi-

114 A. Leiris, You Will Not Have My Hate, transl. by S. Taylor, London 2016. Original: A. Leiris, Vous n'aurezpas ma haine, Paris 2016.

115 Proclaimed by the United Nations General Assembly in Paris on 10 December 1948, the UDHR is widely recognized as having inspired and paved the way for the adoption of more than seventy human rights treaties, applied today on a permanent basis at global and regional levels (all containing references to it in their preambles). At <https://www.un.org/en/about-us/universal-declaration-of-human-rights $>, 2$ March 2021.

116 1: 1789, at <https://www.conseil-constitutionnel.fr/en/declaration-of-human-and-civic-rights-of26-august-1789>, 2 March 2021.

2: 1948: Already mentioned in note 114 .

3: 1961: Adopted at the first Congress of African Jurists in Lagos, Nigeria in 1961, and referred to as the 'Law of Lagos,' calling on African governments to adopt an African convention on human rights with a court and a commission, at <https://www.achpr.org/legalinstruments/detail?id=49>, 2 March 2021. 
cal rights were meaningless and liable to disappear whenever entire human communities were subjected to poverty and fear. It is only when a minimum of physical and economic security is assured, and protection from attack, from hunger, cold or illness, that people can concern themselves with the defense of freedoms or property rights. ${ }^{17}$

One of the lessons of the 1930s was that poverty and mass unemployment pave the way for dictatorship, and that freedom is impossible where physical or economic insecurity prevail. This was the very reason for the declaration of social rights after the Second World War. ${ }^{18}$

As for the structure of these 'second generation' rights, some of them (such as the freedom of association) have the same form as traditional rights, that is, they guarantee a sphere of individual autonomy. However, the rights that cannot be exercised without the presence of a collective organization (the right to health care, for example), far from constituting a regression into a prelegal sphere, have on the contrary anticipated a development that currently affects certain 'first generation' rights, for example property rights. Globalization has shifted the focus to 'intellectual,' not material, property, that is, to what jurists call 'intangible assets' such as trademarks, patents or copyright. ${ }^{119}$

Today, as the Covid 19 virus is spreading around the world, we debate whether pharmaceutical firms right to have their patents protected should yield before the right of the African poor to have access to vaccination.

Human rights always fall within the scope of human laws. Today's challenges are best viewed in light of history and complex transdisciplinary knowledge. Such a light is used and transmitted by an amazingly astute jurist, professor at the prestigious Collège de France. In his fascinating rigorously documented book Homo Juridicus. On the Anthropological Function of the Law, Alain Supiot provides us with the contemporary knowledge we need to confront in order to update the issue of human rights today. He tells us that they are a useful creed in today's world: It is really in terms of belief that the question of human rights should be addressed, and any reflection on the subject should begin by acknowledging their dogmatic nature and that they are articles of faith inspired by the values of Western Christianity. But their dogmatic character should not lead us to disqualify them. A dogma is also a resource and perhaps an utterly indispensable one, since human beings must assign a sense to their lives even though no sense is apparent. (...) But if human rights are to continue to fulfil this dogmatic function, they must be reinterpreted and transformed, in step with the historical development of science and technology and their geographical extension. This presupposes that the non-Western world appropriates human rights, enriching their meaning and scope. Only then will they cease to be a creed imposed on humanity and become a common dogmatic resource open to interpretation by all peoples. ${ }^{120}$

Alain Supiot stresses that this Religion, in which we invite all to commune, is deeply rooted in the long history of the belief systems that have dominated and fashioned the West.

117 A. Supiot, Homo Juridicus... , p. 199. Original: A. Supiot, Homo juridicus..., p. 294.

118 Ibid., p. 199 \& p. 295.

119 Ibid., p. 200 \& p. 295.

120 Ibid., p. $186 \&$ pp. $276-277$. 
These human 'rights to' (to employment, to social security, to education and culture) are clearly the result of Western historical development. They are informed by concepts - such as 'work', implicitly salaried - that do not correspond to those of Southern countries. The definition of the 'human' of 'human rights' is therefore specifically Western, and so too is the very vocabulary of law and rights, which has nothing immediately universal about it and in fact expresses a specifically Western system of beliefs. The idea that the world is governed by universal and unbending laws is proper to the civilizations of the Book.

This figure of the universal and atemporal being to which all our declarations of rights refer is very different from that found in other civilizations, where people may feel to be inhabited by several beings, see themselves as part of a whole that traverses and exceeds them, and value the effacement of individual will.

The fact that non-Western civilizations have had to, or still have to, adopt Western legal ideas creates the illusion that they have been converted to our legal culture. But this is to fail to understand that the idea of law was either simply imposed by colonial powers or else imported as a necessary condition for trade with the West, and in no way expresses the human or social values of the civilization. ${ }^{121}$

Nevertheless, Supiot is convinced that human rights is now constitutive of humanity's self-knowledge. As a body of dogma, a Religion of Humanity, it allows us to approach the question of 'values' in a globalized world from a different perspective. Still, for a reflection on the 'values common to humanity' to make headway, it must begin by avoiding the temptation of fundamentalism.

The fundamentalist interpretation of human rights can take three forms: messianism, when people seek to impose their literal interpretation on the whole world; particularism, when, on the contrary, human rights are made into a sign of the West's superiority over other civilizations which are deemed incapable, in the name of cultural relativity, of adopting them; and lastly scientism, where human rights are reduced to the dogmas of biology or economics, considered as the true and inviolable laws of human behavior. ${ }^{122}$

Supiot tells us that the interpretation of human rights should not be restricted to that provided by Western countries but open to all civilizations.

In the preamble of the Universal Declaration of Human Rights from 1948. it reads that a common understanding of these rights and freedoms is of the greatest importance for the full realization of this pledge. ${ }^{123}$ Indeed, if a resource is held in common, it must logically be able to be appropriated by more than one. Assisting this appropriation is the only way to respect the proper character of each civilization, while not treating it as self-enclosed.

Such a development is possible as recent history provides numerous examples of countries that have successfully appropriated Western modernity without being destroyed by it.

121 Ibid., p. 190 \& p. 282.

122 Ibid., p. 193 \& p. 286.

123 At <https://www.un.org/en/about-us/universal-declaration-of-human-rights>, 2 March 2021. Already mentioned in note 114 . 
Such a development is required to ensure better cross-cultural understanding and learning upon which the future of all humans and their planet depends.

Supiot provides us with examples of the inadequacies of the current declaration. A lot of the terms used rely on a specific Western historical situation that today can make sense in different ways in different social contexts, not only across the world but also at different times in the same countries.

Prohibiting child labor, for instance, in societies without schools, deprives children of their only opportunity of learning their own culture. In contrast, if this prohibition were opened out to a range of interpretations, including African ones, the West might be forced to reflect on its own ways of bringing up children, which are not necessarily exemplary, and it might discover for example that school-work is also a form of work, even if it is ignored by labor legislation. The 'common value' in this case is not hard to find: it is the right of a child to be a child, and to be treated as such, according to his or her needs and abilities. In this light, the notion of 'decent work,' which is currently advocated by the ILO, 65, seems a much richer and more promising notion than all the indignant probibitions that know nothing of the civilizations to which they apply. The same argument could be put forward as regards equality between the sexes, which is certainly not a mathematical equality corresponding to a uniformly and universally applicable formula, but an equality in difference and an always fragile equilibrium dependent on respect for these very differences. It is at any rate understandable that African women do not appreciate Westerners coming and telling them, as the missionaries did before them, what attitudes to adopt in relation to men. ${ }^{124}$

Alain Supiot points out that it is Africa which has so far made the most remarkable attempt, in legal terms, to appropriate human rights, in the form of the African Charter on Human and Peoples' Rights of 27 June 1981. ${ }^{125}$

As its name suggests, the charter integrates the individual rights that feature in Western declarations, but does so within a conception of the human being not as an isolated individual subject, but as a being linked to others, whose identity exists as member of a number of communities. That is why the charter features subjects of rights other than the individual and the State, and towards which the individual and the State have obligations (articles 27, 29): there is the family, not solely as object of an individual right, as in article 16 of the Universal Declaration, but as 'custodian of morals and traditional values recognized by the community' (article 18), which the State has a duty to assist; and there is the people, which has the right 'to struggle against foreign domination, be it political, economic or cultural' and which is understood within a framework where 'the reality and respect of peoples' rights should necessarily guarantee human rights' (article 20). ${ }^{126}$

Our conception of human rights in the West might gain from opening the doors of interpretation and pondering some of these 'African values', in the light of which we might be able to solve some of our own problems. For instance, not isolating human beings from their

124 A. Supiot, Homo juridicus... p. 206. Original: A. Supiot, Homo juridicus..., p. 303.

125 At <https://www.achpr.org/legalinstruments/detail?id=49>, 2 March 2021. Already mentioned in note 114.

126 A. Supiot, Homo juridicus..., pp. 206-207. Original: A. Supiot, Homo juridicus.., p. 304. 
relationships with others (article 28); establishing the principle of solidarity (article 29); asserting the right of peoples to the protection of their environment (article 24); or safeguarding the educational role of the family (article 18 and 29). These values do not figure in the Universal Declaration of Human Rights of 1948, but they are no less universal for all that. ${ }^{127}$

Alain Supiot also notes that the systems of social solidarity developed in the framework of Welfare States are undergoing a major crisis.

They have proved a failure when exported to many Southern countries, where bonds of personal solidarity remain the only bonds which can be relied upon; and in Northern countries they are under fire from the market fundamentalists, while encountering increasing financial difficulties linked notably to the opening up of frontiers, which allows capital and companies to avoid taxes and welfare contributions. The solution to these problems is not provided by the myth of a global society composed of self-sufficient individuals freed from any bonds of solidarity, nor by national systems of solidarity turning in on themselves, since they are the backbone of their society and are therefore obliged to evolve with it. The destabilization of these systems can only be countered by giving an international dimension to the duty to solidarity inherent in the declaration of 'second generation' rights. (...) Furthermore, the principle of solidarity could be drawn upon in new ways, and economic and social rights could be interpreted afresh in the light of the new legal regime of globalized trade. If the international social divide and the conflict of interests between workers in Northern and Southern countries is to be reduced, this reinterpretation must include the ways in which solidarity is conceived and practiced in Southern countries. (...) This reinterpretation of the principle of solidarity naturally welcomes the contributions of all the countries affected by its implementation. Such contributions would help restore the essential function of human rights, which is to channel the effects of people's feelings of omnipotence. As science and technology develop, such feelings have come to threaten the very survival of humanity. It is the true function of law to protect us from this threat. ${ }^{128}$

Supiot has noticed that faced with the globalization of the market economy, we likewise need mechanisms that will enable a human and social hermeneutics of economic law to emerge.

If the human consequences of the extension of the free market to the whole world are not taken seriously, this movement will not be long-lived. A 'division of labor' is already appearing between international organizations responsible for things (goods and capital) and those responsible for persons (labor, health, social protection, culture and education and so forth).

It is within this context that the question arises of the articulation between the market economy and the values of different civilizations around the world. We will only survive globalization if it is conceived not as a process of homogenizing peoples and cultures, but as a process of unification that thrives on diversity and not on its eradication. The hermeneutics of human rights is a key aspect of the problems raised by the liberalization of trade and financial markets. The disputes that occur as a result of the extension of the free market can

127 Ibid., p. 207 \& p. 305.

128 Ibid., pp. 209-210, 212 \& pp. 308-309, 312. 
and should be an opportunity for these human and fundamental rights to be reinterpreted, instead of perpetuating Northern unilateralism, which has led to the failure to integrate a social clause into international trade agreements. ${ }^{129}$

All this being said, we have to remember that every right implies corresponding or 'correlative' duties in order to see that right respected, protected, or fulfilled. ${ }^{130}$ Indeed, as Samuel Moyn points out, we are now very familiar with the claim that all humans everywhere have rights. But we are much less familiar with the notion that rights are protected by the fulfillment of duties. ${ }^{131}$ Nevertheless, in our global world today the notion of duties must refer to a common good, a global common good. Duties are no longer confined to communities, religions or states. Human rights require global fraternal duties.

\section{BIBLIOGRAPHY}

Affergan F., Exotisme et Altérité. Essai Sur Les Fondements D’une Critique De Lanthropologie, Paris 1987.

Allès D., La Part Des Dieux - Religion Et Relations Internationales, Paris 2021.

Arendt H., "Concluding Remarks", in H. Arendt (ed.), The Origins of Totalitarianism, with an introduction by S. Power, New York 2004 [1951].

Armogathe J.-R., "Vitoria, Francisco de (1492 env.-1546)", in Encyclopedia Universalis, Paris 2021, at <https://www.universalis.fr/encyclopedie/francisco-de-vitoria/>.

Balandier G., Le Désordre. Eloge Du Mouvement, Paris 1988.

Bayly Ch.A., The Birth of the Modern World 1780-1914. Global Connections and Comparisons, Oxford 2005.

Bouchet D., "The Ambiguity of Modern Conception of Autonomy and the Paradox of Culture", ThesisEleven, vol.88, no. 1 (2007),pp.31-54, https://doi.org/10.1177/0725513607072456.

Bouchet D., "Democratic Conscience versus the Madness of Fanatical Terrorism", Knowledge Cultures, vol. 3, no. 1 (2015), pp. 11-19.

Bouchet D., "Desire", in D. Southerton (ed.), Encyclopedia of Consumer Culture, Volume 1, Los Angeles-London 2011, pp. 440-444.

Bouchet D., "Det hellige i sociologisk perspektiv", Paradigma, vol. 3, no. 4 (1989), pp. 31-42.

Bouchet D., "The Innovative Role of Art in the Time of the Absence of the Myth", Chapter 9 , in P. Murphy, E. de la Fuente (eds.), Aesthetic Capitalism, Leiden 2014, pp. 174-194, https:// doi.org/10.1163/9789004274723_011.

Bouchet D., "Kompleksitetsparadigmet. Videnskabsteoretiske betragtninger om vor tids udfordringer med udgangspunkt i Edgar Morins værker”, Paradigma, vol. 1, no. 1 (1986), pp. 7-17.

129 Ibid., p. 217 \& pp. 313-314.

130 S. Moyn, Human Rights and the Uses of History, London-New York 1997, p. 152.

131 Ibid. 
Bouchet D., "Lévi-Strauss, Claude (1908-2009)”, in J.D. Wright (ed.), International Encyclopedia of the Social and Behavioral Sciences. 2nd Edition, Oxford 2015, pp. 905-911, https:// doi.org/10.1016/B978-0-08-097086-8.61237-0.

Bouchet D., "Marketing, Violence and Social Cohesion: First Steps to a Conceptual Approach to the Understanding of the Normalising Role of Marketing", Journal of Marketing Management, vol. 34, no. 11-12, pp. 1048-1062, https://doi.org/https://doi.org/10.1080/026725 7X.2018.1521114.

Bouchet D., "The Specificity of Human Aesthetics”, Knowledge Cultures, vol. 3, no. 3 (2015).

Burkert W., Creation of the Sacred. Tracks of Biology in Early Religions, Cambridge, Mass.-London 1996.

Camus A., Actuelles I. Ecrits Politiques, Paris 1997.

Camus A., Essais, Paris 1965.

Camus A., Resistance, Rebellion, and Death, transl. and introduction by J. O'Brien, New York 1961.

Carrière J.-C., Verhaeghe J.-D., La Controverse De Valladolid, Paris 1992.

Castoriadis C., "Culture in a Democratic Society (1994)." In The Castoriadis Reader. Edited by David Ames Curtis, Oxford-Malden 1997, pp. 338-348.

Castoriadis C., The Imaginary Institution of Society, transl. by K. Blamey, Cambridge 1987 [1975].

Castoriadis C., L'institution Imaginaire De La Société, Paris 1975.

Castoriadis C., "La culture dans une société démocratique", in C. Castoridialis (ed.), La montée de l'insignifiance. Les carrefours du labyrinthe IV., Paris 1996, pp. 194-205.

Castoriadis C., La Montée De L'insignifiance. Les Carrefours Du Labyrinthe Iv, Paris 1996.

Castoriadis C., "Le cache-misère de l'éthique", in C. Castoriadis, La montée de l'insignifiance. Les carrefours du labyrinthe IV, Paris 1996, pp. 206-220.

Castoriadis C., World In Fragments. Writings On Politics, Society, Psychoanalysis, and The Imagination, ed. and transl. by D.A. Curtis, Stanford 1997.

Clastres P., Chronique Des Indiens Guayaki, Paris 1972.

Clastres P., La Société Contre L'etat. Recherches D’anthropologie Politique, Paris 1974.

Clastres P., Society Against the State, transl. by R. Hurley in collaboration with A. Stein, Oxford 1977 [1974].

Clottes J. (ed.), La Grotte Chauvet : L'art Des Origines, Paris 2010.

Comte-Sponville A., Petit Traité Des Grandes Vertus, Paris 1995.

Comte-Sponville A., A Short Treatise on the Great Virtues. The Uses of Philosophy in Everyday Life, London 2001 [1996].

Cyrulnik B., The Dawn of Meaning (La Naissance Du Sens), New York 1993 [1991].

Cyrulnik B., La Naissance Du Sens, Paris 1995.

Cyrulnik B., La Naissance Du Sens, Paris 1991.

Cyrulnik B., Les Nourritures Affectives, Paris 1993.

Davis N.Z., Trickster Travels: A Sixteenth-Century Muslim between Worlds. The Search for Leo Africanus, Paris 2006.

Douglas M., Purity and Danger, London 1970.

Durkheim É., The Elementary Forms of the Religious Life, transl. by J.W. Swain, London 1968 [1912]. 
Durkheim É., Les Formes Élémentaires De La Vie Religieuse. Le Système Totémique En Australie 1979 [1912].

Dussel E., "Bartolomé de Las Casas. Spanish Historian and Missionary", in Encyclopedia Britannica, pp. 684-686, at <https://www.britannica.com/biography/Bartolome-de-Las-Casas>.

Gauchet M., The Disenchantment of the World. A Political History of Religion, transl. by O. Burge, Princeton 1997 [1985].

Gauchet M., Le Désenchantement Du Monde. Une Histoire Politique De La Religion, Paris 1985. Geertz C., The Interpretation of Cultures, New York 1973.

Jacquard A., Petite Philosophie À L'usage Des Non-Philosophes, Paris 1997.

Kennedy P., The Rise and Fall of the Great Powers. Economic Change and Military Conflict from 1500 to 2000, New York 1989.

Las Casas B. de, Brevísima relación de la destrucción de las Indias, San Juan 2019 [1552].

Las Casas B. de, Del único modo de atraer a todos los pueblos a la verdadera religión. Monterrey 1992 [1537].

Las Casas B. de, Très brève relation de la destruction des Indes, Paris 1979 [1542].

Lefort C., "The Idea of Humanity and the Project of Universal Peace", in idem (ed.), Writing. The Political Test, transl. by D.A. Curtis, Durham-London 2000, pp. 142-158.

Lefort C., "L'idée d'humanité et le projet de paix universelle", in C. Lefort (ed.), Ecrire à l'épreuve du politique, Paris 1992, pp. 227-246.

Leiris A., Vous N'aurez Pas Ma Haine, Paris 2016.

Leiris A., You Will Not Have My Hate, transl. by S. Taylor, London 2016.

Maalouf A., Leo the African, transl. by P. Sluglett, London 1994 [1986].

Maalouf A., Léon L'africain, Samarcande \& Les Jardins De Lumière, Paris 1992.

MacCulloch D., A History of Christianity. The First Three Thousand Years, London 2010.

Machado A. Campos De Castilla. Edición De José Luis Cano, Madrid 1986 [1912].

Mann Ch.C., 1491. The Americas before Columbus, New York 2005.

Mann Ch.C., 1493. How Europe's Discovery of the Americas Revolutionized Trade, Ecology and Life on Earth, New York 2011.

Miquel P., Les Guerres De Religion, Paris 1980.

Montaigne M. de, The Complete Essays, transl. and ed. with an introduction and notes by M.A. Screech, Harmondsworth 2003 [1580-1588].

Montaigne M. de, Essais. Tome I. Edition De Maurice Rat, Paris 1962.

Montaigne M. de, Les Essais Livre Ii. Édition Critique D'andré Tournon, Paris 1998 [1580].

Montaigne M. de, Les Essais. Édition Établie Par Jean Balsamo, Michel Magnien Et Catherine Magnien-Simoni, Paris 2007 [1580-1588].

Morin E., Introduction À La Pensée Complexe, Paris 1990.

Morin E., La Complexité Humaine, Paris 1994.

Morin E., La Méthode I : 1. La Nature De La Nature; 2. La Vie De La Vie; 3. La Connaissance De La Connaissance, Paris 2008.

Morin E., La Méthode Ii : 3. Les Idées; 4. L’humanité De L'humanité; 5. Éthique, Paris 2008.

Morin E., On Complexity, transl. by R. Postel, Cresskill 2008.

Morin E., On the Definition of Complexity, The United Nations University 1985.

Morin E., Pour Sortir Du Vingtième Siècle, Paris 1981. 
Nancy J.-L., Le Sens Du Monde. Édition Revue Et Corrigée, Paris 2001 [1993].

Nancy J.-L., The Sense of the World, transl. by J.S. Librett, Minneapolis 1998 [1993].

Obama B., On an New Beginning. Remarks by the President at Cairo University, June 4, 2009, at $<$ https://obamawhitehouse.archives.gov/the-press-office/remarks-president-cairo-univer sity-6-04-09>.

Pogge T., World Poverty and Human Rights. Second Edition, Cambridge-Malden 2008.

Römer T., L'invention de Dieu. Postface inédite, Paris 2017 [2014].

Rousseau J.-J., Du contrat social ou principes du droit politique, Paris 1962 [1762].

Rousseau J.-J., The Social Contract and Other Later Political Writings, ed. and transl. by V. Gourevitch, Cambridge 1997.

Roux J.-P., Les Explorateurs Au Moyen Agge, Paris 1961.

Roux J.-P., Les Explorateurs Du Moyen-Âge, Paris 1995 [1985].

Soler J., "Les raisons de la Bible: règles alimentaires hébraïques", in J.-L. Flandrin, M. Montanari (eds.), Histoire de l'alimentation, Paris 1996, pp. 73-84.

Soler J., Sacrifices et interdits alimentaires dans la Bible, Paris 2006 [2004].

Supiot A. (ed.), Homo Juridicus. Essai Sur La Fonction Anthropologique Du Droit, Paris 2005.

Supiot A. (ed.), Homo Juridicus. On the Anthropological Function of the Law, transl. by S. Brown, London-New York 2007 [2005].

Supiot A., La Force D’une Idée. Suivi De Lidée De Justice Sociale D'alfred Fouillée, Paris 2019.

Sutherland L., "The Divergent Cosmopolitanisms of Hannah Arendt", in A. Kumar Giri (ed.), Beyond Cosmopolitanism. Towards Planetary Transformations, Singapore 2018, pp. 149-179, https://doi.org/10.1007/978-981-10-5376-4_10.

Testart A., Art et religion de Chauvet À Lascaux, Paris 2016.

Wilson E.O., On Human Nature, Cambridge 1978.

Witzel E.J.M., The Origins of the World's Mythologies, New York 2013, https://doi.org/10.1093/ acprof:oso/9780195367461.001.0001.

Dominique BOUCHET was born in Paris in 1949, where he was educated (masters, postmasters, Ph.D.) in business economics at ESSEC, international economics at Sorbonne, sociology at Paris 7, town planning at ENPC, and Latin American Studies at IHEAL. He has held appointments in international economics, sociology, and social psychology and has taught in five languages in 24 countries. Since 1991 Dr Bouchet has been Chair Professor of International Marketing at the University of Southern Denmark, where he served for 13 years as the Director of Doctoral Programs in Social Sciences. His interests span a wide area including epistemology, economics, sociology, philosophy, history, art, anthropology, semiotics, design, creativity, and markets as they relate to social change, cultural differences, cultures of consumption, education, and international relations. For "his capacity as an original and transcending researcher and scholar" Bouchet was awarded the Danish Researchers' Prize in 2007. He has organized eleven international doctoral courses, each lasting for four to nine days, in Cross Cultural Communication, Business Research, Advanced Qualitative Methods, Consumption Theory, and Semiotic, Textual, and Visual Analysis. 